\title{
Geology and Petrology of Metavolcanic Rocks in the Neoarchean Mundo Novo Greenstone Belt, Eastern São Francisco Craton, NE Brazil: Tectonic Setting Considerations
}

\author{
Ricardo Ramos Spreafico ${ }^{1 *}$,Johildo Salomão Figueiredo Barbosa ${ }^{1}$, Antônio Marcos Vitória de Moraes ${ }^{2}$ and \\ Francisco Dias de Souza Júnior ${ }^{2}$
}

${ }^{1}$ Institute of Geosciences, Federal University of Bahia, Brazil

${ }^{2}$ Mining Company of Bahia State, Brazil

*Corresponding author: Ricardo Ramos Spreafico, Mining Company of Bahia State and Institute of Geosciences, Federal University of Bahia, Brazil

\begin{abstract}
Field and petrological data of metakomatiite, eastern and western metabasalts and metadacite were used to propose an intraoceanic or intracontinental provenance for the Neoarchean Mundo Novo Greenstone Belt (MNGB), eastern São Francisco Craton. Despite deformation, the metakomatiite preserves the spinifex texture and the eastern metabasalt's pillow lava structure. The metavolcanics are recovered by an ocean floor lithological association composed of chemical metasedimentary rocks and the western metabasalt hosts ocean floor hydrothermal alteration zones. The eastern metabasalt plots in the IAT and MORB fields and western metabasalt is mainly in the MORB field in the $\mathrm{Zr}$ vs. Zr/Y diagram, suggesting nearby oceanic settings. Heterogeneous crustal assimilation and metamorphism during the Rhyacian-Orosirian explain the mineralogical differences between the two metabasalts. The metakomatiite and metabasalts feature a vector from the MORB-OIB array to the volcanic arc array in the Nb/Yb vs. Th/Yb diagram, similar to the intraoceanic arc-basin system of the Archean greenstone belts. The average (La/Yb) $\mathrm{N}$ ratio of 8.87 for the metadacite indicates a crustal contamination in subducting oceanic crust. An intraoceanic provenance in arc-basin settings and oceanic crust assimilations are proposed for the Neoarchean MNGB, which was posteriorly compressed between cratonic blocks during the Rhyacian-Orosirian and lies in the Contendas-Jacobina Lineament.
\end{abstract}

Keywords: Mundo Novo Greenstone Belt; metavolcanic rocks; Intraoceanic Setting; Petrology; São Francisco Craton

\section{Introduction}

The Neoarchean Mundo Novo greenstone belt (MNGB), in the eastern boundary of the Gavião Block [1-3] and eastern portion of the São Francisco Craton, and lying within the Contendas-Jacobina Lineament [4], NE Brazil, hosts the Zn-Pb Fazenda Coqueiro deposit and has been a subject of study since the 1970s [5-12] (Figures 1A-1C). However, the MNGB lacks detailed discussions on its tectonic setting of volcanism, mainly concerning its intraoceanic or intracontinental provenance. Greenstone belts are highly varied Archean geological entities that contain a vast diversity of rocks. Generally, their rocks experienced multiple stages of deformation, metamorphism and metasomatic alteration due their great age and diversity of geotectonic settings, which was intruded by mafic, ultramafic and granitoid rocks [13]. Moreover, the intraoceanic or intracontinental provenance of volcanic rocks in Archean greenstone belts has been a recurring discussion topic and whole-rock chemical tools have been constantly applied for such research purposes [14-17]. The predominance of subaqueously deposited basalt and komatiite has been interpreted in a wide variety of geological settings proposed for greenstone belt terrains in intraoceanic crust, ranging from primitive island arcs to plume-related submarine plateaus, mid-ocean ridges (including ophiolites) and back-arc basins [18-22]. Furthermore, the intraoceanic Archean greenstone belts present a set of evidence as follows: basalt and komatiite occurrence, the absence of zircon xenocrysts, Mid-Ocean Ridge Basalt (MORB) and Island Arc Tholeiitic (IAT) geochemical patterns, and Th enrichment due to crustal contamination processes [16]. The crustal contamination, however, would have been produced by subduction components, metamorphism, intraoceanic contamination, crustal recycling, high Th-Nb proxy and delamination $[16,17]$. 


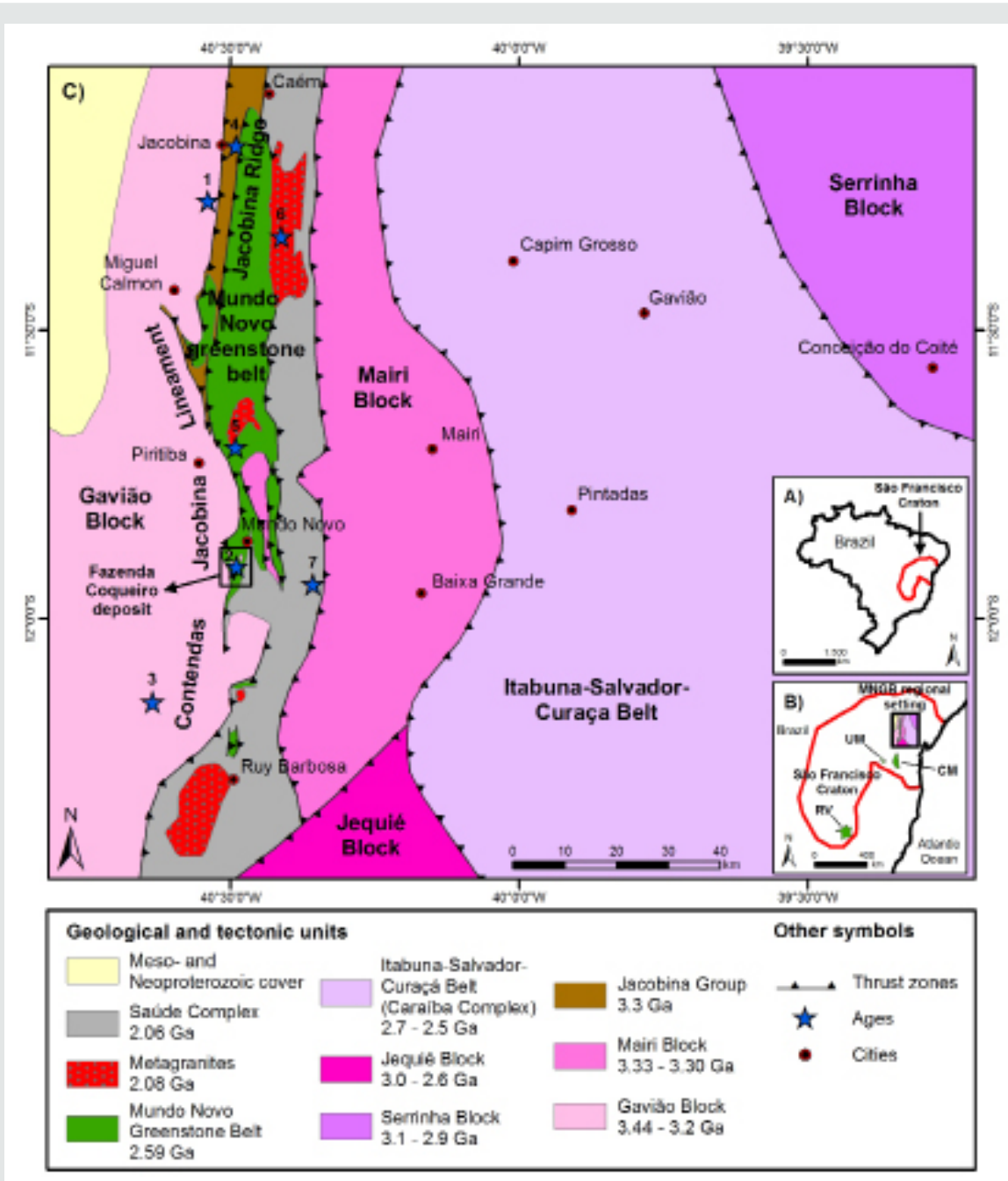

Figure 1: A) Location of the São Francisco Craton in NE Brazil. B) Study area in the eastern portion of the São Francisco Craton and other greenstone belts and volcano-sedimentary sequences: CM: Contendas-Mirante; RV: Rio das Velhas; UM: Umburanas. C) Regional tectonic setting where the MNGB is inserted (modified from Barbosa and Sabaté [1,2,3]). Ages in the points highlighted on the map: 1- $3442 \pm 2 \mathrm{Ma}$ (U-Pb zircon, TTG; Mougeot [34]); 2- $3303 \pm 11 \mathrm{Ma}$ (U-Pb zircon, metarhyolite from the Gavião Block obtained by Zincone et al. [11]); 3- $3292 \pm 3$ Ma (U-Pb zircon, metagranite from the Gavião Block obtained by Zincone et al. [11]); 4- 3500 - $3220 \mathrm{Ma}$ (U-Pb zircon, quartzite from the Jacobina Group obtained by Teles et al. [35]); 5- $259521 \mathrm{Ma}$ (U-Pb zircon, metadacite from the MNGB obtained by Spreafico et al. [36]); 6- $208018 \mathrm{Ma}$ (U-Pb monazite, Cachoeira Grande granite obtained by Leite [37]); 7- 206812 Ma (U-Pb zircon, biotite schist from the Saúde Complex obtained by Zincone et al. [38]).

The metabasalt of the Nova Lima Group in the Archean Rio das Velhas greenstone belt of the southern São Francisco Craton (Figure $1 B)$, for example, has been considered as derived from an oceanfloor setting based on a pillow lava structure and an association with chemical sediments and volcanic rocks [23]. Moreover, the geochemical pattern of this metabasalt suggests a submarine plateau setting and crustal contamination rocks; the felsic volcanic rocks would indicate the presence of an island arc or back-arc type setting [24]. In the Neoarchean Contendas-Mirante volcanosedimentary sequence, south of the Contendas-Jacobina Lineament Figure $1 \mathrm{~b}$, which contains geochemical and age equivalences with the MNGB, intraoceanic basalt occurrences have been interpreted as being related to banded iron formation [25]. The South Abitibi $[26,27]$, Barberton et al. $[21,28,29]$ and Isua et al. $[15,30]$ are other examples of intraoceanic interpretations for Archean greenstone belts, which Pearce [16] discusses in his examination of the ocean floor's origin with crustal contamination along their geological evolution based on a Th-Nb proxy. Despite the contamination issues of analyzing Archean rocks, the geochemical pattern of the modern Mariana Arc, which indicates an arc-basin system in oceanic crust, was properly used to compare to older intraoceanic settings in the $\mathrm{Nb} / \mathrm{Yb}$ vs. Th/Yb diagram [16,31]. The intracontinental provenance of volcanic rocks in Archean greenstone belts, on the other hand, has been related to oceanic-continent subduction processes or with the genesis on ensialic settings [16]. Greenstones of the Wawa belt in the Superior Province, for example, were formed in an arc-related association [14], the Umburanas greenstone belt in the eastern São Francisco Craton Figure 1B was formed over a continental crust [32]. Bickle et al. [33] concluded that the continental provenance for Archean greenstone belts could not easily identify complete ophiolitic sequences, which would thus explain a possible oceanic origin; the presence zircon xenocrysts, geochemical and isotopic 
evidence for crustal contamination, intrusive relationships with older basement rocks and their internal stratigraphy would also indicate continental provenance. Therefore, field, petrographic and whole-rock chemical data from the metakomatiite, eastern and western metabasalts and metadacite in the MNGB, completed by the mineral chemistry of the two metabasalts, were used to characterize the metavolcanic rocks and study the tectonic setting of the MNGB. The intraoceanic provenance of the volcanic rocks rather than the intracontinental provenance and a comparison with other Archean greenstone belts were also considered. The insertion of the Neoarchean MNGB within the regional geologic context in the eastern portion of the São Francisco Craton and the subsequent tectonic events were also contemplated.

\section{Geological Setting}

The eastern portion of the São Francisco Craton, where the MNGB is situated (state of Bahia), was formed through the amalgamation of four Archean blocks during the Paleoproterozoic continentcontinent collision [1-3] the Gavião, Serrinha and Jequié blocks and the Itabuna-Salvador-Curaçá Belt Figure 1c. The Paleoproterozoic event captured the MNGB and surrounding crust between the cratonic blocks, and the uplift caused by this event possibly resulted in the erosion and the formation of Paleoproterozoic sedimentary basins, such as the uppermost sequence of the MNGB and the Saúde Complex. Briefly, the MNGB is in contact to the west with $3.4 \mathrm{Ga}$ [34] Tonalite-Trondhjemite-Granodiorite (TTG) basement rocks and subordinate metagranites in the Gavião Block and to the east

Table 1: Compilation of regional geochronological data of the MNGB and surrounding units.

\begin{tabular}{|c|c|c|c|c|c|}
\hline $\begin{array}{l}\text { Geological/tec- } \\
\text { tonic unit }\end{array}$ & Lithotype & Age & Methods & Mineral dated & Author \\
\hline \multirow{2}{*}{ Saúde Complex } & \multirow{2}{*}{ Biotite schist } & \multirow{2}{*}{$2068 \pm 12 \mathrm{Ma}$} & $\mathrm{U}-\mathrm{Pb}$ & \multirow{2}{*}{ Detrital zircon } & \multirow{2}{*}{ [38] } \\
\hline & & & (LA-MC-ICP-MS) & & \\
\hline $\begin{array}{c}\text { Cachoeira Grande } \\
\text { granite }\end{array}$ & Leucogranite & $2080 \pm 18 \mathrm{Ma}$ & $\mathrm{U}-\mathrm{Pb}$ (Electron microprobe) & Monazite (crystallization age) & [37] \\
\hline \multirow{2}{*}{$\begin{array}{l}\text { Upper sequence } \\
\text { ss(MNGB) }\end{array}$} & \multirow{2}{*}{ Quartzite } & \multirow{2}{*}{$2133 \pm 14 \mathrm{Ma}$} & $\mathrm{U}-\mathrm{Pb}$ & \multirow{2}{*}{ Detrital zircon } & \multirow{2}{*}[54]{} \\
\hline & & & (LA-ICP-MS) & & \\
\hline \multirow{2}{*}{$\begin{array}{l}\text { Mundo Novo } \\
\text { greenstone belt }\end{array}$} & \multirow{2}{*}{ Metadacite } & \multirow{2}{*}{$2595 \pm 21 \mathrm{Ma}$} & $\mathrm{U}-\mathrm{Pb}$ & \multirow{2}{*}{ Zircon (crystallization age) } & \multirow{2}{*}{ [36] } \\
\hline & & & (LA-ICP-MS) & & \\
\hline \multirow{2}{*}{$\begin{array}{l}\text { Itabuna-Salvador- } \\
\text {-Curaçá Belt }\end{array}$} & Tonalitic granulite & $2574 \pm 6 \mathrm{Ma}$ & U-Pb (SHRIMP) & Zircon (crystallization age) & {$[41]$} \\
\hline & Enderbite & $2695 \pm 12 \mathrm{Ma}$ & $\mathrm{U}-\mathrm{Pb}$ (SHRIMP) & Zircon (crystallization age) & {$[42]$} \\
\hline \multirow{3}{*}{ Jequié Block } & Granulites & $2715 \pm 29 \mathrm{Ma}$ & $\mathrm{U}-\mathrm{Pb}$ (SHRIMP) & Zircon (crystallization age) & {$[40]$} \\
\hline & \multirow{2}{*}{ Charnockite } & \multirow{2}{*}{$2900 \pm 24 \mathrm{Ma}$} & \multirow{2}{*}{$\mathrm{Rb}-\mathrm{Sr}$} & Whole rock & \multirow{2}{*}{ [39] } \\
\hline & & & & (crystallization age) & \\
\hline \multirow[t]{2}{*}{ Serrinha Block } & Granitoid & $\begin{array}{c}2989 \pm 11 \mathrm{Ma} 3072 \pm \\
2 \mathrm{Ma} 3162 \pm 26 \mathrm{Ma}\end{array}$ & U-Pb (SHRIMP) & Zircon (crystallization age) & [45] \\
\hline & Gneiss, migmatite & $3152 \pm 5 \mathrm{Ma}$ & U-Pb (SHRIMP) & Zircon (crystallization age) & {$[43,44]$} \\
\hline \multirow{2}{*}{ Jacobina Group } & \multirow{2}{*}{ Quartzite } & \multirow{2}{*}{$3500-3220 \mathrm{Ma}$} & $\mathrm{U}-\mathrm{Pb}$ & \multirow{2}{*}{ Detrital zircon } & \multirow{2}{*}[35,54,55,56]{} \\
\hline & & & (LA-MC-ICP-MS) & & \\
\hline \multirow{2}{*}{ Mairi Block } & \multirow{2}{*}{ Orthogneiss } & \multirow{2}{*}{$3.33-3.30 \mathrm{Ga}$} & $\mathrm{U}-\mathrm{Pb}$ & \multirow{2}{*}{ Zircon (crystallization age) } & \multirow{2}{*}[50]{} \\
\hline & & & (LA-SF-ICP-MS) & & \\
\hline
\end{tabular}

Citation:Ricardo R S, Johildo Salomão F B, Antônio M V d M, Francisco D d S Jr. Geology and Petrology of Metavolcanic Rocks in the Neoarchean Mundo Novo Greenstone Belt, Eastern São Francisco Craton, NE Brazil: Tectonic Setting Considerations. J Mining \& Mech Eng 1(1)- 2019. JOMME.MS.ID.000105. DOI: 10.32474/JOMME.2019.01.000105. and south with paragneiss in the Saúde Complex with a maximum age between 2.20 and 2.06 Ga [38] Figure 2. To the north and northwest, the MNGB is in contact with quartzites in the Jacobina Group, which were deposited between 3.55 and 3.22 Ga [35], and Paleoproterozoic granitic intrusives.

Additionally, the geological setting includes granulites (3.0 Ga) and multiple charnockite intrusions (2.7 and $2.6 \mathrm{Ga}$ ) in the Jequié Block et al. $[39,40]$, the Itabuna-Salvador-Curaçá Belt $(2574 \pm 6$ Ma and $2695 \pm 12$ Ma obtained by Oliveira et al. [41], Silva et al. [42]; respectively, and the Serrinha Block $3152 \pm 5$ Ma obtained by Oliveira et al. [43,44]; $2989 \pm 11 \mathrm{Ma}, 3072 \pm 2 \mathrm{Ma}$ and $3162 \pm$ 26 Ma obtained by Rios et al. [45], although the Itabuna-SalvadorCuraçá Belt and Serrinha Block are far from the MNGB, they are important for understanding the collisional Paleoproterozoic tectonic context of the study area Figure 1C. Table 1 shows regional geochronological data from the MNGB and surrounding units. The eastern margin of the Gavião Block is in tectonic contact with the lithologies of the MNGB Figure $1 \mathrm{C}$ and is composed of TTG gneiss and migmatites that host mafic rock enclaves [46], metagranites and metarhyolites [11]. This block corresponds to the basement of the MNGB. Three groups of TTG gneiss are described in the Gavião Block: two groups are trondhjemitic with $\mathrm{U}-\mathrm{Pb}$ zircon ages (SHRIMP) of $3403 \pm 5 \mathrm{Ma}$ and $3158 \pm 5 \mathrm{Ma}[47,48]$, and the other group, with granodioritic compositions, includes the $3225 \pm 10 \mathrm{Ma}$ Aracatu granitoid [46]. The Gavião Block age, near the MNGB, is 3.4 Ga [34], but metarhyolites with ages of $3303 \pm 11 \mathrm{Ma}[11,49]$ and metagranites, such as Boa Sorte at $3291 \pm 2.5 \mathrm{Ma}$, occur as well [11]. 


\begin{tabular}{|c|c|c|c|c|c|}
\hline \multirow{5}{*}{ Gavião Block } & \multirow{2}{*}{ Metagranite } & \multirow{2}{*}{$3291 \pm 2.5 \mathrm{Ma}$} & $\mathrm{U}-\mathrm{Pb}$ & \multirow{2}{*}{ Zircon (crystallization age) } & \multirow{2}{*}{ [11] } \\
\hline & & & (LA-ICP-MS) & & \\
\hline & \multirow{2}{*}{ Metarhyolite } & \multirow{2}{*}{$3303 \pm 11 \mathrm{Ma}$} & $\mathrm{U}-\mathrm{Pb}$ & \multirow{2}{*}{ Zircon (crystallization age) } & \multirow{2}{*}[11,49]{} \\
\hline & & & (LA-ICP-MS and SHRIMP) & & \\
\hline & TTG & $3442 \pm 2 \mathrm{Ma}$ & U-Pb (ID-TIMS) & Zircon (crystallization age) & [34] \\
\hline
\end{tabular}

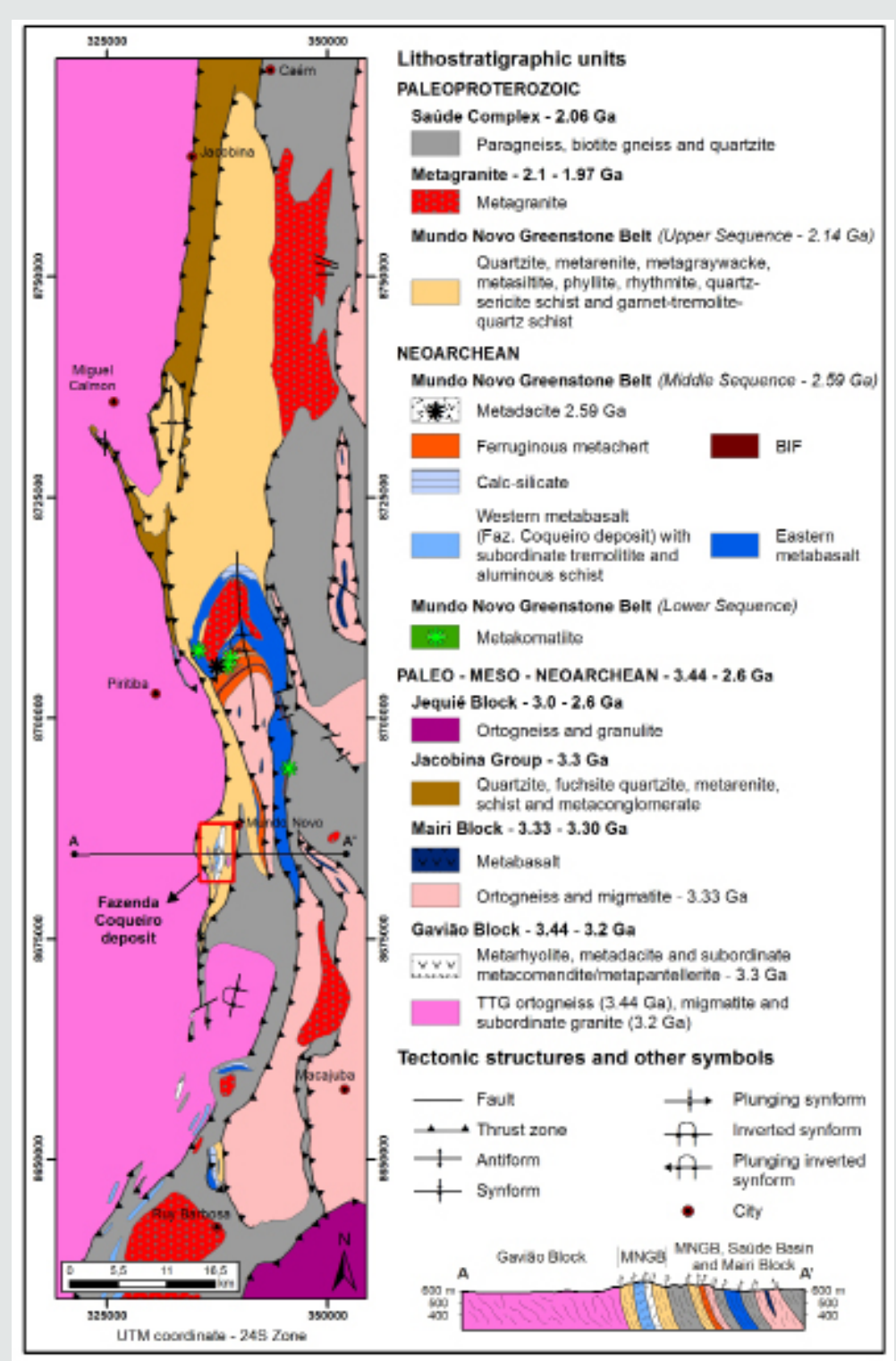

Figure 2: Geologic map of the MNGB and adjoining units. Modified and updated from Loureiro [8], Mascarenhas and Silva [9] and Souza et al. [69].

The Mairi Block, composed of gneiss, migmatites, and granitic and tonalitic orthogneiss, with some occurrences of basic and ultrabasic bodies [49] to the east and southeast of the MNGB, is in tectonic contact with thrust zones with a west vergence. The LA-ICP-MS U-Pb zircon ages of 3.33 Ga and 3.30 Ga [50] for the orthogneiss in the Mairi Block indicate that this complex is coeval with the Gavião Block and, therefore, the two may have been joined at the time of their formation. The Jacobina Group is in tectonic contact with the MNGB along thrust zones, with all zones striking north south and verging to the west Figure 1c with the Gavião Block in the footwall. The Jacobina Group comprises metaconglomerates that host an important gold deposit, quartzites, metarenites, phyllites, chlorite schists and quartz-sericite schists [10] deposited in a passive margin setting [51]. This group has a depositional age, based on detrital zircons, between 3500 Ma and $3220 \mathrm{Ma}$ $[35,54,55]$, with a large portion of the zircon populations situated between 3.3 Ga and 3.4 Ga [35,56]. Jacobina Ridge represents an Archean supracrustal sequence with a maximum age of $3.28 \mathrm{Ga}$, and its sources are likely rocks from both the plutonic-volcanic system and the TTG suite in the Gavião Block [11]. 
The MNGB, which Zincone et al. [11] referred to as the Mundo Novo supracrustal belt, is inserted into the Contendas-Jacobina Lineament and is divided into three stratigraphic sequences - a lower sequence (ultramafic rocks), a middle sequence (mafic and felsic igneous rocks and clastic and chemical metasedimentary rocks) and an upper sequence (siliciclastic metasedimentary rocks; [36]). Carbonate and argilic-chloritic hydrothermal alteration zones in the ocean floor setting have been identified and described in the Fazenda Coqueiro deposit related to $\mathrm{Zn}-\mathrm{Pb}$ mineralization hosted in the western metabasalt of the middle sequence [52]. Two ductile and compressional and progressive Paleoproterozoic deformational phases in the MNGB, D1 and D2, are described in the area in a previous study [52]. The D1 deformational phase is characterized by isoclinal and recumbent folds vergent to the west that generated greenschist metamorphic facies rocks. The D2 deformational phase is characterized by a refolding that generated vertical and subvertical axial planes that eventually resulted in the formation of a coaxial interference pattern [53] or compressive and transpressive shear zones, which bound the MNGB lithologies and generated greenschist rocks to amphibolite metamorphic facies. The most prominent brittle structures are east-trending faults and fractures. The age of the MNGB has been previously studied, and geochronological studies have defined the Neoarchean age of the volcanism [36], such as the Paleoproterozoic sedimentation on the top of the sequence [54], which is coeval with the RhyacianOrosirian tectonothermal event $[37,52]$. These rocks lie upon the 3.4 - 3.2 Ga basement rocks of the northern part of the Gavião Block comprised of TTG gneiss, metagranites and metarhyolites $[11,34,46,47,48,49]$. The Saúde Complex occurs to the east of the MNGB Figure 1c, where the two units are in tectonic contact along west-vergent thrust zones. This complex comprises aluminous paragneiss, biotite gneiss and subordinate quartzites that are widely distributed in a north-south trend with significant occurrences in the Mundo Novo region and in the eastern portion of the Jacobina Ridge et al, $[7,10,12,57]$ Figure $1 \mathrm{C}$. The maximal depositional age of 2.06 Ga [38] for the Saúde Complex again indicates the presence of a basin near the MNGB in the Paleoproterozoic; however, the rocks in the Saúde Complex were subjected to a higher metamorphic grade than the sedimentary rocks at the top of the MNGB along the tectonic contact.

Finally, Rhyacian-Orosirian granites are present along the Contendas-Jacobina Lineament [37,52] Figure 1C. In general, these granites are undeformed leucogranites, comprising quartz, feldspar, biotite and muscovite with some occurrences of garnet and sillimanite [58]. The Cachoeira Grande granite, for example, is a peraluminous leucogranite situated to the northeast of the MNGB, which has an average age of $2080 \pm 18 \mathrm{Ma}$ [37] and is coeval with the Rhyacian-Orosirian granitic intrusions in the MNGB [36,52].

\section{Materials and Methods}

The study of the metavolcanic rocks of the MNGB and considerations of the tectonic setting involved petrography, mineral chemistry and whole-rock chemical analyses. For petrography, we analyzed 127 thin sections of metakomatiite, eastern and western metabasalts and metadacite to determine the mineralogical composition, textures and microstructures of the rocks using the ZEISS Axio Scope.A1 microscope provided by Companhia Baiana De Pesquisa Mineral (CBPM). The mineral abbreviations used on photomicrographs mainly follow those of Kretz [59] and Siivola and Schmid [60] and are completed with abbreviations of Whitney and Evans [61]. Six of the thin sections were used for mineral chemistry analysis to detail the mineral differences between the two metabasalt types complementing the petrographic studies. Thus, a CAMECA SX50 electron microprobe was used with four Wavelength-Dispersive Spectroscopes (WDS) and one Kevex Energy Dispersive Spectroscope (EDS) of the University of Brasília. The standards used are naturals and synthetics with defined compositions, such as albite (for the element $\mathrm{Na}_{2} \mathrm{O}$ ), andradite (for the elements $\mathrm{CaO}$ and $\mathrm{FeO}$ ), forsterite (for the element $\mathrm{MgO}$ ), microcline (for the elements $\mathrm{Al}_{2} \mathrm{O}_{3}, \mathrm{SiO}_{2}$ and $\mathrm{K}_{2} \mathrm{O}$ ), $\mathrm{MnTiO}_{3}$ (for the element $\mathrm{TiO}_{2}$ ) and $\mathrm{MnTiO}_{3}$ (for the element $\mathrm{MnO}$ ). The analyzed spots were selected on polished sections in plagioclase (6 spots in 5 samples), amphibole ( 6 spots in 5 samples), pyroxene ( 4 spots in 2 samples), ilmenite ( 2 spots in 2 samples), titanite ( 2 spots in 2 samples) and biotite (1 spot in 1 sample) grains Table 2 . The chemical contents are expressed by $\mathrm{SiO}_{2}, \mathrm{TiO}_{2}, \mathrm{Al}_{2} \mathrm{O}_{3}, \mathrm{FeO}, \mathrm{MnO}, \mathrm{MgO}$, $\mathrm{CaO}, \mathrm{Na}_{2} \mathrm{O}$ and $\mathrm{K}_{2} \mathrm{O}$. The data were processed using the Gabbrosoft spreadsheets (http://www.gabbrosoft.org) and the plagioclase results were plotted in the ternary diagram of feldspar; the amphiboles were plotted in the calcic amphibole diagrams [62] and the pyroxene in the classification diagram of pyroxenes [63] using the Minpet program. The EDS data were used to show evidence of manganiferous ilmenite, and in this case, a backscattered electron image was obtained.

Table 2: Electron microprobe data of minerals in the eastern and western metabasalts (wt.\%).

\begin{tabular}{|c|c|c|c|c|c|c|c|c|c|c|c|c|}
\hline $\begin{array}{l}\text { Geologic unit } \\
\text { classification }\end{array}$ & $\begin{array}{l}\text { Sample } \\
\text { ID }\end{array}$ & Mineral & $\mathrm{SiO}_{2}$ & $\mathrm{TiO}_{2}$ & $\mathrm{Al}_{2} \mathrm{O}_{3}$ & $\mathrm{FeO}$ & MnO & MgO & $\mathrm{CaO}$ & $\mathrm{Na}_{2} \mathrm{O}$ & $\mathrm{K}_{2} \mathbf{O}$ & Sum \\
\hline $\begin{array}{c}\text { Eastern } \\
\text { metabasalt }\end{array}$ & RR-072 & Anorthite & 46.6 & 0.08 & 35.4 & 0.29 & 0 & 0.01 & 18.4 & 1.17 & 0.03 & $1 \mathrm{~s} 02$ \\
\hline $\begin{array}{c}\text { Eastern } \\
\text { metabasalt }\end{array}$ & RR-072 & Anorthite & 46.2 & 0 & 35.5 & 0.38 & 0 & 0.01 & 18.3 & 1.09 & 0.02 & 101.5 \\
\hline $\begin{array}{c}\text { Eastern } \\
\text { metabasalt }\end{array}$ & RR-018A & Bytownite & 49.3 & 0.08 & 32.9 & 0.16 & 0.11 & 0.02 & 15.8 & 2.56 & 0.1 & 101 \\
\hline $\begin{array}{c}\text { Eastern } \\
\text { metabasalt }\end{array}$ & RR-011C & Oligoclase & 62.4 & 0 & 22.8 & 0.09 & 0 & 0 & 3.5 & 9.2 & 0.08 & 98.06 \\
\hline $\begin{array}{c}\text { Eastern } \\
\text { metabasalt }\end{array}$ & RR-072 & Fe-Hornblende & 44.1 & 0.3 & $14 . s 2$ & 17.3 & 0.19 & 8.92 & 11.8 & 1.08 & 0.24 & 98.1 \\
\hline
\end{tabular}

Citation:Ricardo R S, Johildo Salomão F B, Antônio M V d M, Francisco D d S Jr. Geology and Petrology of Metavolcanic Rocks in the Neoarchean Mundo Novo Greenstone Belt, Eastern São Francisco Craton, NE Brazil: Tectonic Setting Considerations. J Mining \& Mech Eng 1(1)- 2019. JOMME.MS.ID.000105. DOI: 10.32474/JOMME.2019.01.000105. 


\begin{tabular}{|c|c|c|c|c|c|c|c|c|c|c|c|c|}
\hline $\begin{array}{c}\text { Eastern } \\
\text { metabasalt }\end{array}$ & RR-011C & Mg-Hornblende & 48.3 & 0.12 & 7.27 & 12.5 & 0.24 & 14.3 & 11.1 & 1.53 & 0.14 & 95.4 \\
\hline $\begin{array}{c}\text { Eastern } \\
\text { metabasalt }\end{array}$ & RR-018A & Edenite & 51.5 & 0.18 & 0.62 & 15 & 0.41 & 9.19 & 22.7 & 0.16 & 0.01 & 99.71 \\
\hline $\begin{array}{c}\text { Eastern } \\
\text { metabasalt }\end{array}$ & RR-072 & Hypersthene & 53.1 & 0.19 & 0.55 & 25.9 & 0.6 & 15 & 0.93 & 0.06 & 0 & 96.38 \\
\hline $\begin{array}{c}\text { Eastern } \\
\text { metabasalt }\end{array}$ & RR-072 & Hypersthene & 52.6 & 0.04 & 1 & 26.4 & 0.56 & 15.1 & 1.4 & 0.08 & 0 & 97.14 \\
\hline $\begin{array}{c}\text { Eastern } \\
\text { metabasalt }\end{array}$ & RR-072 & Hypersthene & 52.8 & 0.18 & 0.4 & 26.5 & 0.74 & 15.1 & 0.86 & 0.07 & 0 & 96.69 \\
\hline $\begin{array}{c}\text { Eastern } \\
\text { metabasalt }\end{array}$ & RR-072 & Ilmenite & 0.1 & 50.6 & 0.03 & 45.8 & 0.79 & 0.07 & 0.02 & 0.03 & 0.01 & 97.47 \\
\hline $\begin{array}{c}\text { Eastern } \\
\text { metabasalt }\end{array}$ & RR-072 & Titanite & 16.8 & 42.5 & 1.06 & 25.4 & 0.66 & 0.7 & 14 & 0.03 & 0 & 101.1 \\
\hline $\begin{array}{l}\text { Western } \\
\text { metabasalt }\end{array}$ & $\begin{array}{l}\text { RR-F6- } \\
001\end{array}$ & Oligoclase & 60 & 0.23 & 23.2 & 0.04 & 0 & 0 & 5.09 & 8.71 & 0.04 & 97.26 \\
\hline $\begin{array}{l}\text { Western } \\
\text { metabasalt }\end{array}$ & $\begin{array}{l}\text { RR-F6- } \\
010\end{array}$ & Andesine & 56.8 & 0.03 & 26.9 & 0.14 & 0 & 0 & 9.04 & 6.45 & 0.05 & 99.39 \\
\hline $\begin{array}{l}\text { Western } \\
\text { metabasalt }\end{array}$ & $\begin{array}{l}\text { RR-F1- } \\
001\end{array}$ & Mg-Hornblende & 46.4 & 0.67 & 8.44 & 18.1 & 0.42 & 10.1 & 11.7 & 0.9 & 0.38 & 97.09 \\
\hline $\begin{array}{c}\text { Western } \\
\text { metabasalt }\end{array}$ & $\begin{array}{l}\text { RR-F1- } \\
001\end{array}$ & $\begin{array}{c}\text { Fe- } \\
\text { Tschermakite }\end{array}$ & 40.9 & 0.88 & 11.7 & 27.2 & 0.33 & 3.85 & 11.7 & 0.92 & 1.13 & 98.49 \\
\hline $\begin{array}{l}\text { Western } \\
\text { metabasalt }\end{array}$ & $\begin{array}{l}\text { RR-F6- } \\
010\end{array}$ & $\begin{array}{c}\text { Fe- } \\
\text { Tschermakite }\end{array}$ & 41.3 & 0.89 & 11.3 & 26.9 & 0.37 & 3.91 & 11.6 & 1.03 & 1.06 & 98.35 \\
\hline $\begin{array}{l}\text { Western } \\
\text { metabasalt }\end{array}$ & $\begin{array}{l}\text { RR-F6- } \\
001\end{array}$ & Hypersthene & 51.6 & 0.07 & 0.86 & 27 & 0.66 & 15.6 & 0.73 & 0.13 & 0 & 96.73 \\
\hline $\begin{array}{l}\text { Western } \\
\text { metabasalt }\end{array}$ & $\begin{array}{c}\text { RR-F1- } \\
001\end{array}$ & Biotite & 33.1 & 2.45 & 15.7 & 29 & 0.33 & 4.86 & 0.04 & 0.16 & 9.46 & 95 \\
\hline $\begin{array}{l}\text { Western } \\
\text { metabasalt }\end{array}$ & $\begin{array}{l}\text { RR-F6- } \\
001\end{array}$ & Ilmenite & 0 & 54.9 & 0 & 46.7 & 2.32 & 0.06 & 0.07 & 0 & 0.01 & 104 \\
\hline $\begin{array}{c}\text { Western } \\
\text { metabasalt }\end{array}$ & $\begin{array}{c}\text { RR-F1- } \\
001\end{array}$ & Titanite & 30 & 36.1 & 2.29 & 1.99 & 0.09 & 0.24 & 26.7 & 0.02 & 0.41 & 97.74 \\
\hline
\end{tabular}

The whole-rock chemical analysis of 49 samples was conducted in the SGS-Geosol laboratory. The samples were dried and crushed so $75 \%$ of the sample was smaller than $3 \mathrm{~mm}$. A $300 \mathrm{~g}$ sample was quartered and pulverized (until 95\% was smaller than 105 microns) to form a powder for subsequent processes. The powders were melted at a high temperature with lithium metaborate, and the major, minor, trace, and Rare Earth Elements (REE) were determined using ICP-MS and inductively coupled plasma optical emission spectrometry (ICP-OES) analysis. The international standard samples used are TILL-3 (a description and values are in Lynch et al. [64]) and GRE-05 (reference material from Geostats PTY Ltd.). The error for all analyzed elements in each sample was calculated based on analytical accuracy according to the content of the analyte in the sample, the statistical detection limit and the repeatability limit, and represented in terms of standard deviation $(1 \sigma)$ [65]. The coefficient of variation of the analytical results for each element by sample analyzed, calculated from the standard deviation $(1 \sigma)$, was predominantly lower than $15 \%$, which corresponds to wellrepresented results around the arithmetic mean. Only the samples with a Loss on Ignition (LOI) values of $\leq 5 \%$ were considered. The geochemical data were plotted and interpreted using the GCDKit software [66]. The data in the REE diagram and the (La/Yb) N, Eu/ $\mathrm{Eu}^{*}$ and $(\mathrm{Gd} / \mathrm{Yb}) \mathrm{N}$ ratios were normalized by chondrite values [67], and the data in the multielement diagram were normalized by $\mathrm{N}$ (normal)-MORB values [68].

\section{Results}

\section{Geological, Petrographic and Mineral Chemistry Characterization}

The geologic characterization of the Neoarchean MNGB, which was carried out to support interpretations of the tectonic setting, consisted of field and petrographic observations performed in metavolcanic rocks, including metakomatiite, eastern and western metabasalts and metadacite Figure 2. The mineral chemistry was used to detail petrographic analyses in the eastern and western metabasalts.

\section{Mundo Novo Greenstone Belt}

Many Paleo- to Neoarchean greenstone belts have been characterized as volcano-sedimentary sequences deformed and metamorphosed over time at low to medium grades; they show, from the base to the top, a progressive variation from volcanic (ultramafic, mafic and felsic rocks) to sedimentary rocks (chemical and clastic rocks); they are commonly associated with orthogneisses and are intruded by syn- to posttectonic granites [13]. Based on these concepts, the MNGB is interpreted as part of a typical greenstone belt terrain and is divided into three stratigraphic sequences: the lower sequence, composed of metakomatiite; the middle sequence, composed of eastern and western metabasalts and, subordinately, tremolitite, calc-silicate rock (carbonate hydrothermal alteration 
zone), aluminous schist (argilic-chloritic hydrothermal alteration zone), BIF, ferruginous metachert, metadacite and metarhyolite; and the upper sequence, composed of siliciclastic metasedimentary rocks, such as metarenite, quartzite, metagraywacke, metasiltite,

\section{Lower Sequence}
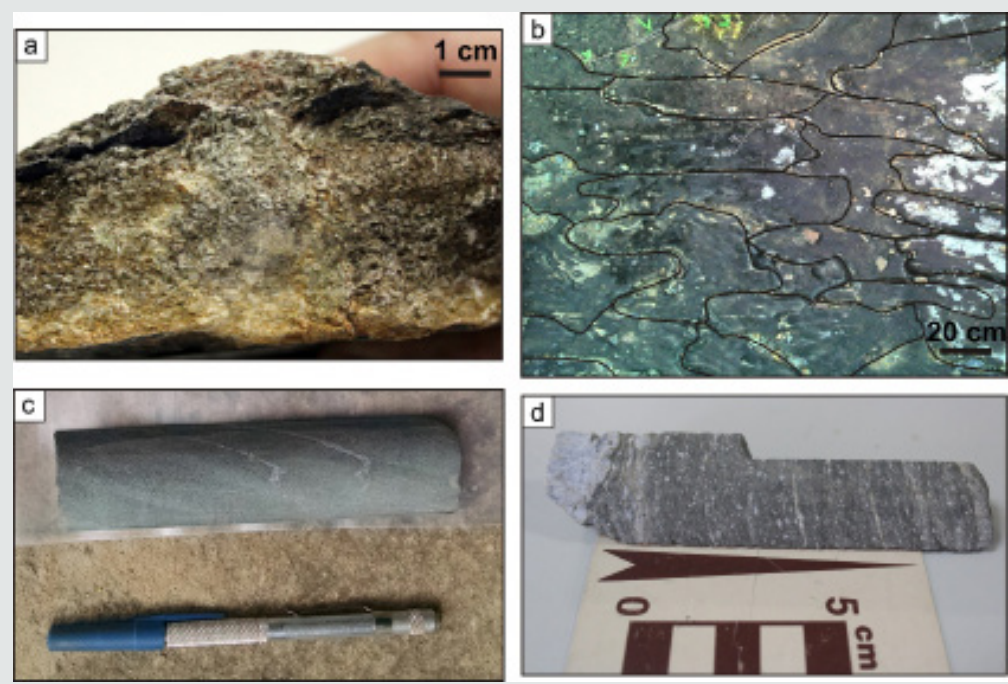

Figure 3: A) Typical spinifex texture of the MNGB metakomatiite. B) Highlighted pillow lava structure of the eastern metabasalt from south of the MNGB. C) Drill hole sample of the western metabasalt in the MNGB. D) Drill hole sample of the porphyroclastic metadacite in the MNGB.
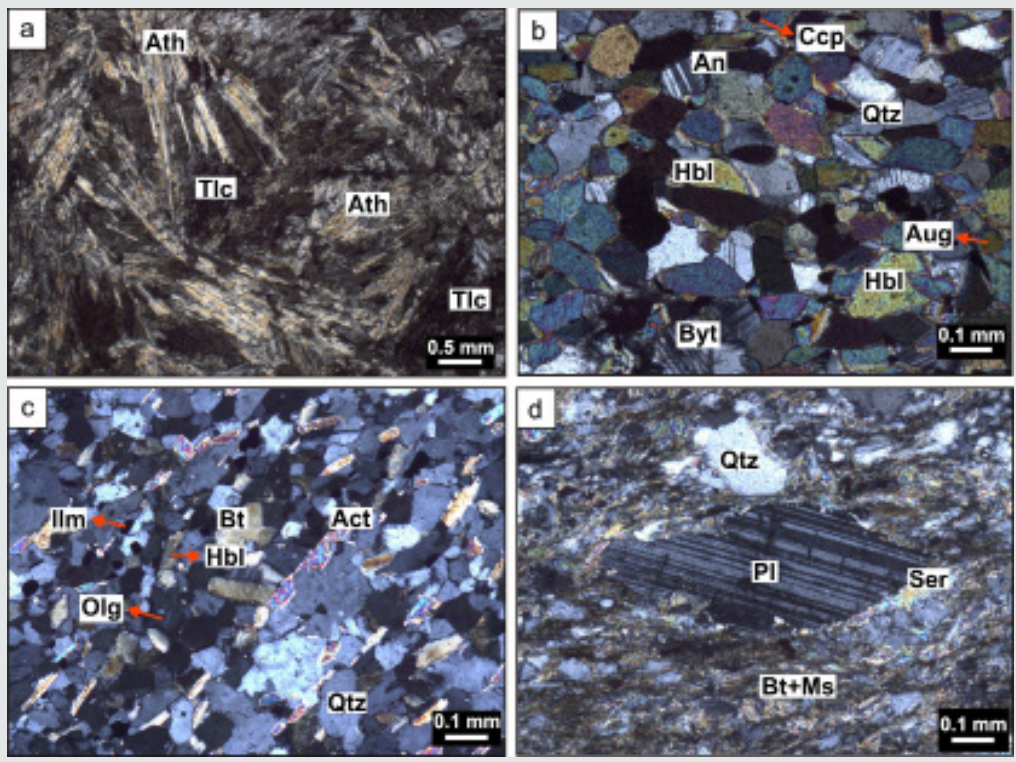

Figure 4: Petrographic images of the MNGB: A) Spinifex texture of metakomatiite composed of pseudomorphic anthophyllite lath in a fine-grained groundmass of talc (XP, 2.5×; sample FD-058A). B) Granonematoblastic texture of the eastern metabasalt (XP, 10x; sample RR-018A). C) Typical very fine-grained texture of the western metabasalt (XP, 10x; sample RR-F6-001). D) Porphyroclast of plagioclase with a sericitized border in a fine-grained groundmass of quartz, biotite and muscovite in the metadacite in the middle sequence of the MNGB (XP, 10×; sample FD-052). Mineral abbreviations: Act: actinolite, An: anorthite, Ath: anthophyllite, Aug: augite, Bt: biotite, Byt: Bytownite, Ccp: chalcopyrite, Hbl: hornblende, Ilm: ilmenite, Ms: muscovite, Olg: oligoclase, Pl: plagioclase, Qtz: quartz, Ser: sericite, and Tlc: talc. XP: crossed polarizers.

The lower sequence is composed of metakomatiite located at the base of the MNGB and comprises the ultramafic volcanic component of the MNGB. The metakomatiite has field relationships with the mafic volcanic rock of the middle sequence; however, these rocks are separated into different sequences due to the mineral content and the textural particularities. There are four restricted occurrences of metakomatiite in the central portion of the MNGB
Figure 2, which are northeast of Mundo Novo city and northeast of Piritiba city. Generally, the metakomatiite of the MNGB has a relict spinifex texture composed of skeletal grains with planar growths that intersect each other Figures 3A and 4B and do not intercept former structures for igneous relicts' texture in komatiites as Arndt [70] described. The fine-grained spinifex texture is identified only in hand samples or by using a hand lens or microscope. The 
metakomatiite of the MNGB has a light green color and a silky aspect and is not magnetic Figure 3A. The olivine and pyroxene crystals are entirely replaced by acicular and prismatic pseudomorphic grains of anthophyllite and tremolite ( $80 \%$ of the rock) with a grain size of $0.5 \mathrm{~mm}$ Figure 4A. The fine-grained groundmass is composed of talc and clinochlore ( $20 \%$ of the rock) without a preferred orientation. Traces of pyrite and pyrrhotite are dispersed in the sample.

\section{Middle Sequence}

The middle sequence is composed of metabasalt and, subordinately, tremolitite, calc-silicate rock, aluminous schist, BIF, ferruginous metachert, metadacite and subordinate metarhyolite; metabasalt and metadacite are the main topics of this study. Metabasalt and metadacite are the terms used in this paper to define the mafic and felsic volcanic components, respectively, of the middle sequence of the MNGB. This terminology was adopted based on the protolith because of its usefulness in determining the original nature of the rock, even though in many cases, a protolith name does not reflect the principal minerals and structural features of the rocks under observation [71]. Moreover, some occurrences of metavolcanic mafic rocks in the MNGB preserve primary structures such as pillow lava. Therefore, the term metabasalt is used in this manuscript rather than amphibolite, which is also correctly used if the texture and mineral content are considered as proposed by Fettes and Desmons [72]. The metabasalts are distributed along a north-south trend Figure 2 and are divided into two coeval groups based on petrography, supported by mineral chemistry analysis, and whole-rock chemical data. The first group, defined as the eastern metabasalt, occurs along the eastern portion of the MNGB and corresponds to the main outcrops of the sequence near Piritiba city and extending to Ruy Barbosa city Figure 2. The second group, defined as the western metabasalt, occurs along the western portion of the MNGB, mainly within the Fazenda Coqueiro deposit (Mundo Novo city), and in a restricted area with a north-south trend near Piritiba city Figure 2.

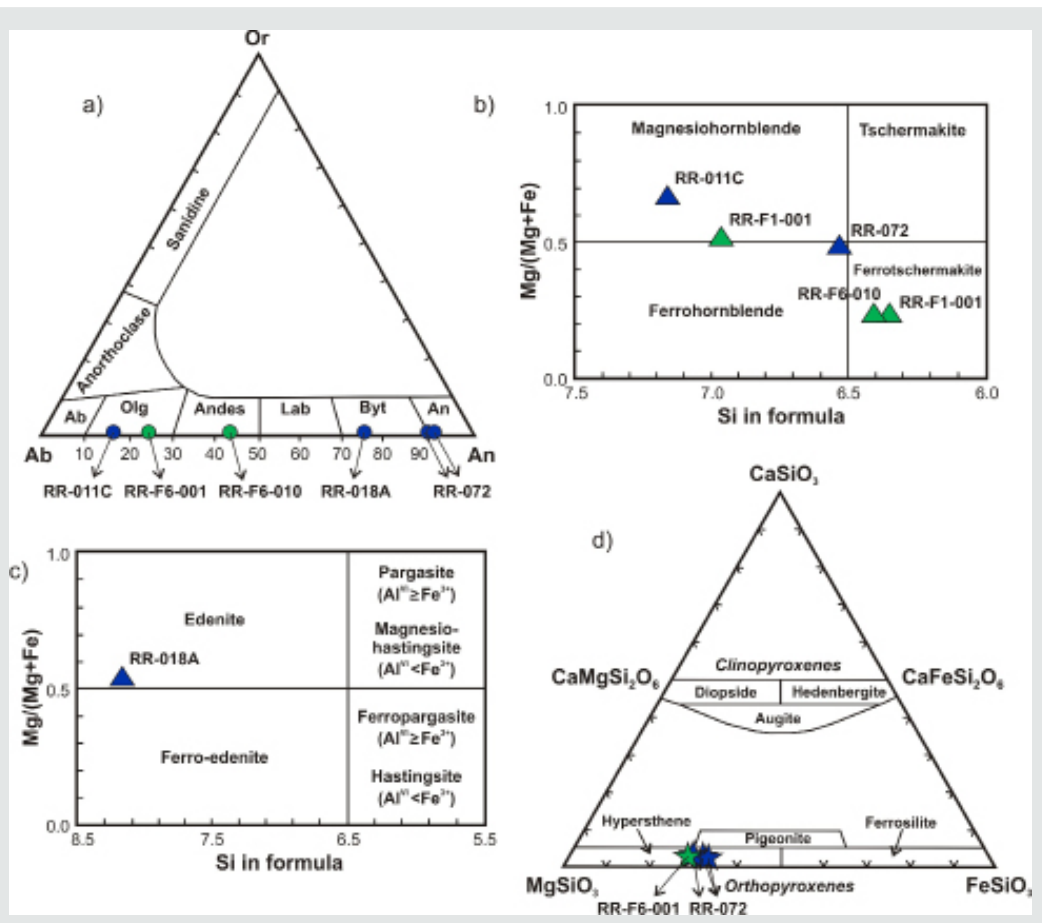

Figure 5: Classification diagrams of minerals in the eastern (blue symbols) and western (green symbols) metabasalts in the MNGB. A) Ternary diagram of feldspar: Ab: albite, Andes: andesine, An: anorthite, Byt: bytownite, Lab: labradorite, Olg: oligoclase, Or: orthoclase. B-C) Classification diagrams of the calcic amphiboles [61]. D) Classification diagram of pyroxenes [63].

The eastern metabasalt preserves the pillow lava structures that occur in a large area to the south of the MNGB Figure 3B. It is composed of anorthite (15\%), bytownite (15\%), magnesiohornblende and ferrohornblende (40\%), small amounts of oligoclase ( $5 \%)$ and low percentages ( $20 \%$ combined) of augite, edenite and quartz, as well as ilmenite and titanite as accessory minerals, and traces of pyrrhotite, chalcopyrite and igneous relicts of hypersthene micrograins identified only in microprobe analysis (5\%; Table 2; Figures 5A, 5B, 5C and 5D). The minerals show polyhedral contacts with nematoblastic and granonematoblastic textures Figure 4B. The western metabasalt hosts the $\mathrm{Zn}$ and $\mathrm{Pb}$ sulfides of the Fazenda Coqueiro deposit, particularly in carbonate hydrothermal alteration zones, and is easily observed from drill hole samples Figure 3C. Based on petrography and mineral chemistry results, this rock is very fine grained and is mainly composed of oligoclase and andesine (50\%), actinolite, magnesiohornblende and ferrotschermakite $(30 \%)$ with a low percentage of quartz, biotite and igneous relicts of hypersthene micrograins (15\%), as well as ilmenite and titanite as accessory minerals (5\%; Table 2; Figures $5 \mathrm{~A}, 5 \mathrm{~B}, 5 \mathrm{C}$ and 5D). Traces of manganiferous ilmenite Figures $6 \mathrm{~A}$ and $6 \mathrm{~B}$, pyrrhotite, pyrite, chalcopyrite, galena, sphalerite and arsenopyrite are also observed. The grains of biotite and actinolite are oriented and define highly developed planes of foliation Figure $4 \mathrm{C}$. 

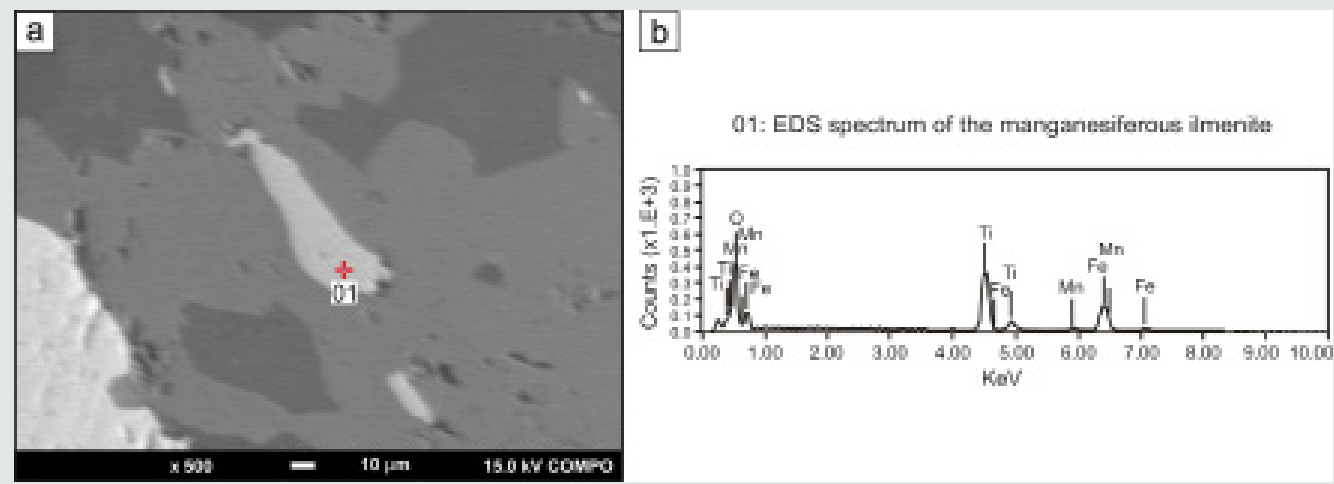

Figure 6: a) Backscattered electron image with the analysis spot and b) the EDS spectrum of the manganiferous ilmenite present in the western metabasalt of the MNGB, as evidence of an ocean floor setting (sample RR-F16-027).

Metadacite and subordinate metarhyolite have restricted occurrences and correspond to the top of the MNGB middle sequence based on field relationships and a felsic mineral content typical of the later stages of volcanism. These units occur to the northeast of Piritiba city and were identified in a drill hole sample obtained by CBPM and in outcrops. These rocks are distributed along a northeast-southwest trend and are in contact with eastern metabasalt and ferruginous metachert Figure 2. The metadacite has a gray color, is strongly foliated and is not magnetic. This rock contains submillimetric porphyroclasts of plagioclase with sericitized borders and quartz (40\% of the rock), which are dispersed in a fine-grained groundmass composed of quartz, plagioclase, biotite, muscovite and sericite $(60 \%$ of the rock; Figures 3D and 4D). The subordinate metarhyolite has a gray color and is fine grained and foliated. It is composed of quartz (25\%), K-feldspar
(40\%), plagioclase (20\%), biotite (10\%) and sericite (5\%). This rock contains granolepidoblastic grains that are submillimetric and highly oriented, tabular crystals of plagioclase (usually sericitized) and grains of quartz, fine biotite and opaque minerals.

\section{Whole-rock chemical characterization}

The lithochemistry characterization of the metavolcanic rocks in the Neoarchean MNGB was used to refine the classification of rocks previously classified on the basis of petrography and mineral chemistry and to evaluate the related petrological processes and tectonic settings. Therefore, this analysis also included samples of metakomatiite of the lower sequence and eastern metabasalt, western metabasalt and metadacite of the middle sequence in the MNGB. The whole-rock chemical data of those rocks are listed in Tables 3,4 and 5 .

Table 3: Whole-rock major and minor oxide chemical data (wt. \%).

\begin{tabular}{|c|c|c|c|c|c|c|c|c|c|c|c|c|c|c|c|}
\hline $\begin{array}{l}\text { Unit and } \\
\text { classifica- } \\
\text { tion }\end{array}$ & Sample ID & W. Long. & S. Lat. & $\mathrm{SiO}_{2}$ & $\mathrm{TiO}_{2}$ & $\mathrm{Al}_{2} \mathrm{O}_{3}$ & $\mathrm{Fe}_{2} \mathrm{O}_{3} \mathrm{t}$ & MnO & MgO & $\mathrm{CaO}$ & $\mathrm{Na}_{2} \mathrm{O}$ & $\mathrm{K}_{2} \mathrm{O}$ & $\mathbf{P}_{2} \mathbf{O}_{5}$ & LOI & Sum \\
\hline \multicolumn{16}{|l|}{$\begin{array}{c}\text { Mundo Novo } \\
\text { greenstone } \\
\text { belt }\end{array}$} \\
\hline $\begin{array}{l}\text { Metakoma- } \\
\text { tiite }\end{array}$ & RR-011B & $40^{\circ} 25^{\prime} 02.20^{\prime \prime}$ & $11^{\circ} 48^{\prime} 39.22^{\prime \prime}$ & 47.01 & 0.25 & 7.33 & 10.18 & 0.22 & 24.46 & 2.99 & 0.08 & 0.03 & 0.005 & 5.49 & 98.055 \\
\hline $\begin{array}{l}\text { Metakoma- } \\
\text { tiite }\end{array}$ & FD-058A & $40^{\circ} 28^{\prime} 45.53^{\prime \prime}$ & $11^{\circ} 41^{\prime} 43.47^{\prime \prime}$ & 57.22 & 0.07 & 2.19 & 6.12 & 0.11 & 24.38 & 2.42 & 0.05 & 0.03 & 0.005 & 4.52 & 97.12 \\
\hline $\begin{array}{l}\text { Metakoma- } \\
\text { tiite }\end{array}$ & FD-070 & $40^{\circ} 28^{\prime} 36.03^{\prime \prime}$ & $11^{\circ} 41^{\prime} 39.19^{\prime \prime}$ & 55.02 & 0.07 & 2.81 & 9.38 & 0.23 & 18.91 & 7.4 & 0.11 & 0.03 & 0.005 & 4.03 & 98 \\
\hline $\begin{array}{c}\text { Eastern } \\
\text { metabasalt }\end{array}$ & RR-006 & $40^{\circ} 25^{\prime} 40.85^{\prime \prime}$ & $11^{\circ} 53^{\prime} 04.26^{\prime \prime}$ & 49.78 & 0.83 & 14.05 & 11.97 & 0.21 & 8.1 & 12.53 & 0.96 & 0.25 & 0.04 & 0.55 & 99.27 \\
\hline $\begin{array}{l}\text { Eastern } \\
\text { metabasalt }\end{array}$ & RR-014B & $40^{\circ} 30^{\prime} 21.91^{\prime \prime}$ & $11^{\circ} 41^{\prime} 40.20^{\prime \prime}$ & 50.49 & 1 & 13.71 & 13.42 & 0.22 & 6.33 & 10.69 & 2.2 & 0.26 & 0.06 & 1.22 & 99.6 \\
\hline $\begin{array}{c}\text { Eastern } \\
\text { metabasalt }\end{array}$ & RR-018A & $40^{\circ} 30^{\prime} 07.88^{\prime \prime}$ & $12^{\circ} 13^{\prime} 43.29^{\prime \prime}$ & 48.93 & 1.04 & 14.18 & 14.11 & 0.23 & 7.16 & 11.39 & 2.1 & 0.26 & 0.07 & 0.52 & 99.99 \\
\hline $\begin{array}{c}\text { Eastern } \\
\text { metabasalt }\end{array}$ & RR-018B & $40^{\circ} 30^{\prime} 07.94^{\prime \prime}$ & $12^{\circ} 13^{\prime} 43.35^{\prime \prime}$ & 51.33 & 1.07 & 13.74 & 14.04 & 0.24 & 7.26 & 10.41 & 2.55 & 0.26 & 0.08 & 0.53 & 101.51 \\
\hline $\begin{array}{c}\text { Eastern } \\
\text { metabasalt }\end{array}$ & RR-018C & $40^{\circ} 30^{\prime} 08.01^{\prime \prime}$ & $12^{\circ} 13^{\prime} 43.42^{\prime \prime}$ & 52.48 & 1.1 & 14.19 & 13.39 & 0.21 & 5.68 & 11.57 & 1.95 & 0.18 & 0.1 & 0.43 & 101.28 \\
\hline
\end{tabular}

Citation:Ricardo R S, Johildo Salomão F B, Antônio M V d M, Francisco D d S Jr. Geology and Petrology of Metavolcanic Rocks in the 


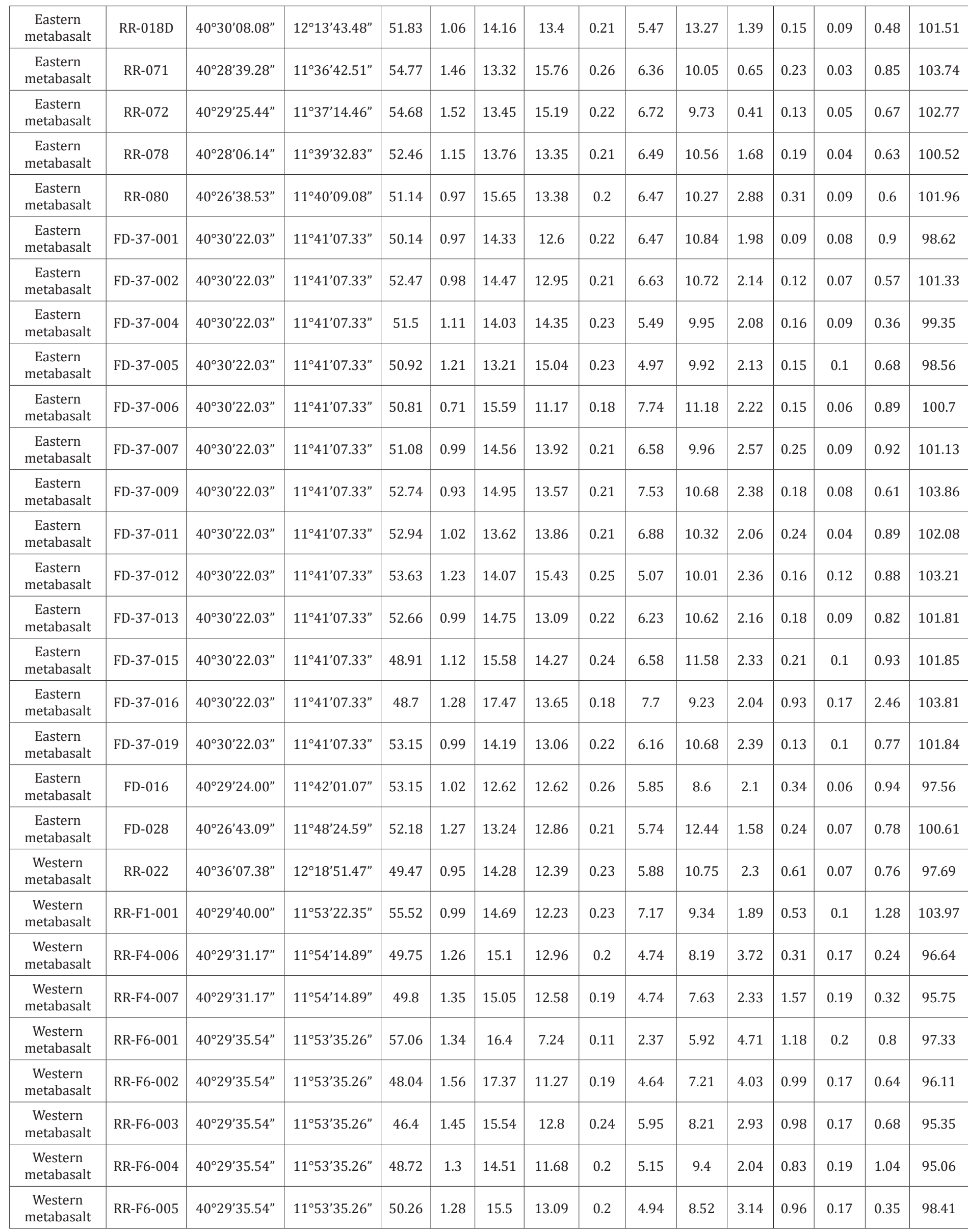




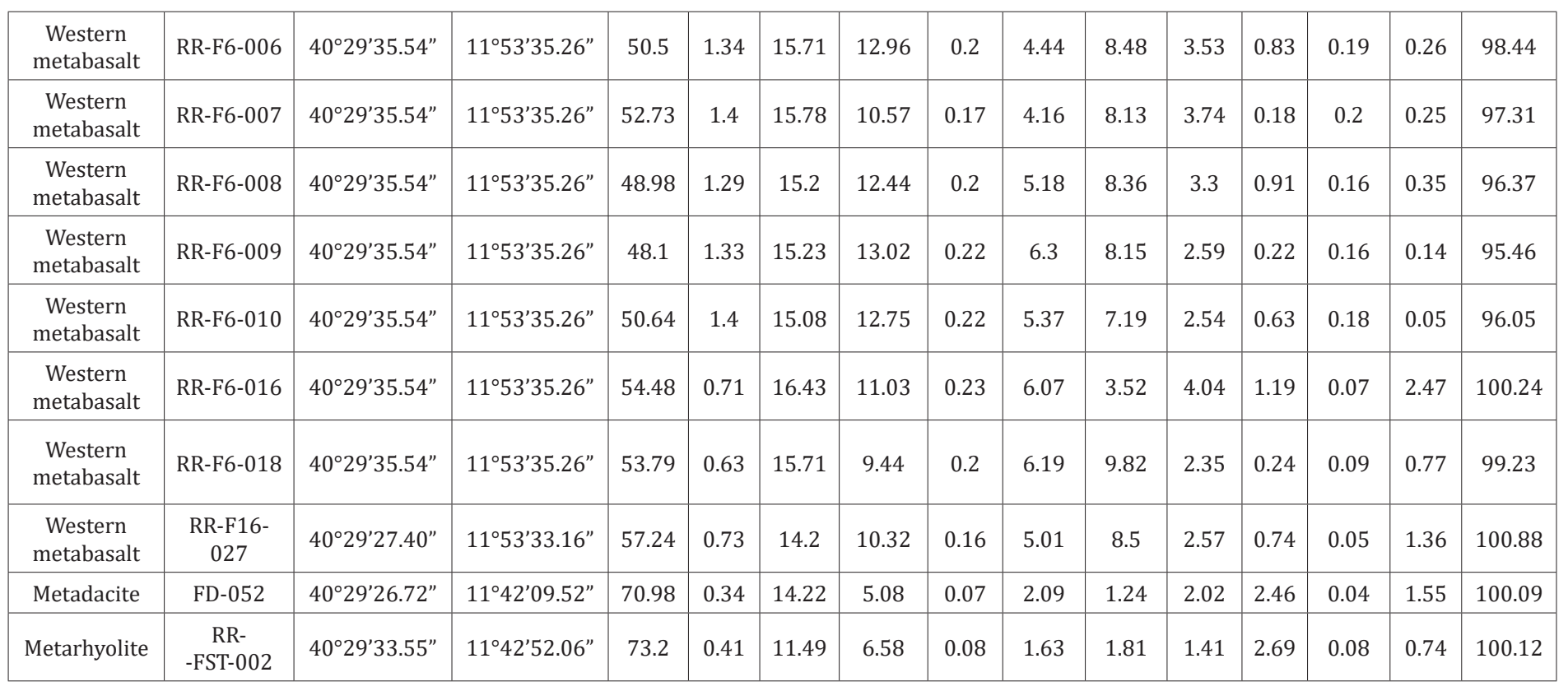

Table 4: Whole-rock REE chemical data (ppm).

\begin{tabular}{|c|c|c|c|c|c|c|c|c|c|c|c|c|c|c|c|}
\hline Unit and classification & Sample ID & La & $\mathrm{Ce}$ & $\operatorname{Pr}$ & Nd & $\mathrm{Sm}$ & Eu & Gd & $\mathbf{T b}$ & Dy & Ho & Er & $\mathrm{Tm}$ & $\mathbf{Y b}$ & $\mathbf{L u}$ \\
\hline \multicolumn{16}{|l|}{$\begin{array}{l}\text { Mundo Novo Greenstone } \\
\text { Belt }\end{array}$} \\
\hline Metakomatiite & RR-011B & 9.5 & 13.2 & 1.18 & 3.8 & 0.6 & 0.2 & 0.68 & 0.12 & 0.74 & 0.16 & 0.49 & 0.07 & 0.5 & 0.07 \\
\hline Metakomatiite & FD-37-017 & 7.2 & 12.6 & 1.62 & 6.7 & 1.4 & 0.43 & 1.56 & 0.21 & 1.49 & 0.3 & 0.94 & 0.13 & 0.9 & 0.13 \\
\hline Metakomatiite & FD-058A & 7.1 & 6.5 & 1.3 & 5.3 & 1.2 & 0.42 & 1.6 & 0.26 & 1.6 & 0.32 & 1 & 0.14 & 0.8 & 0.025 \\
\hline Metakomatiite & FD-070 & 4.9 & 3.7 & 1.17 & 4.7 & 1.3 & 0.51 & 1.74 & 0.29 & 1.81 & 0.41 & 1.11 & 0.19 & 1.1 & 0.11 \\
\hline Eastern metabasalt & RR-006 & 5 & 10.2 & 1.46 & 7 & 2.1 & 0.76 & 2.71 & 0.46 & 3.01 & 0.63 & 1.88 & 0.26 & 1.7 & 0.26 \\
\hline Eastern metabasalt & RR-011C & 10.7 & 24.1 & 3.15 & 14.4 & 3.7 & 1.04 & 4.02 & 0.64 & 3.92 & 0.79 & 2.25 & 0.3 & 1.8 & 0.27 \\
\hline Eastern metabasalt & RR-014B & 6.4 & 11.9 & 1.95 & 9.3 & 2.9 & 1 & 3.8 & 0.69 & 4.83 & 1.03 & 3.09 & 0.45 & 2.9 & 0.44 \\
\hline Eastern metabasalt & RR-018A & 7 & 16.3 & 2.22 & 10.3 & 2.9 & 1 & 3.73 & 0.66 & 4.31 & 0.93 & 2.72 & 0.41 & 2.6 & 0.39 \\
\hline Eastern metabasalt & RR-018B & 7.3 & 13.4 & 1.87 & 9.1 & 2.8 & 0.9 & 3.54 & 0.61 & 4.17 & 0.89 & 2.69 & 0.38 & 2.5 & 0.38 \\
\hline Eastern metabasalt & RR-018C & 9.3 & 20.9 & 2.66 & 12.1 & 3.2 & 1.04 & 3.9 & 0.68 & 4.42 & 0.96 & 2.88 & 0.41 & 2.7 & 0.41 \\
\hline Eastern metabasalt & RR-018D & 8 & 18 & 2.31 & 10.7 & 2.8 & 0.98 & 3.58 & 0.63 & 4.16 & 0.91 & 2.67 & 0.38 & 2.5 & 0.39 \\
\hline Eastern metabasalt & RR-071 & 11.6 & 19.1 & 2.9 & 13.1 & 3.4 & 1.06 & 4.63 & 0.69 & 4.52 & 0.87 & 2.54 & 0.33 & 2.1 & 0.32 \\
\hline Eastern metabasalt & RR-072 & 11 & 24.6 & 2.93 & 13.9 & 3.8 & 1.28 & 4.67 & 0.77 & 4.6 & 0.94 & 2.6 & 0.37 & 2.2 & 0.37 \\
\hline Eastern metabasalt & RR-078 & 10 & 12.8 & 2.19 & 10.3 & 3.1 & 1.17 & 4.41 & 0.75 & 5.28 & 1.09 & 3.39 & 0.5 & 3.3 & 0.51 \\
\hline Eastern metabasalt & RR-080 & 10.1 & 14.1 & 1.96 & 8.9 & 2.7 & 0.99 & 3.95 & 0.71 & 4.69 & 0.99 & 3.09 & 0.43 & 2.8 & 0.46 \\
\hline Eastern metabasalt & FD-37-001 & 6.1 & 12.6 & 1.83 & 8.9 & 2.5 & 0.99 & 3.62 & 0.64 & 4.28 & 0.88 & 2.76 & 0.38 & 2.6 & 0.4 \\
\hline Eastern metabasalt & FD-37-002 & 5 & 11.3 & 1.7 & 8.4 & 2.5 & 0.96 & 3.44 & 0.63 & 4.21 & 0.9 & 2.63 & 0.37 & 2.5 & 0.39 \\
\hline Eastern metabasalt & FD-37-004 & 5.7 & 13.7 & 2.08 & 9.9 & 3.4 & 1.22 & 4.39 & 0.79 & 5.28 & 1.15 & 3.22 & 0.5 & 3.3 & 0.49 \\
\hline Eastern metabasalt & FD-37-005 & 6.5 & 14.9 & 2.26 & 10.5 & 3.2 & 1.12 & 4.55 & 0.78 & 5.16 & 1.13 & 3.4 & 0.49 & 3.1 & 0.49 \\
\hline Eastern metabasalt & FD-37-006 & 4.9 & 8.4 & 1.2 & 6.2 & 1.9 & 0.7 & 2.73 & 0.49 & 3.09 & 0.68 & 1.96 & 0.3 & 1.9 & 0.28 \\
\hline Eastern metabasalt & FD-37-007 & 6.2 & 12 & 1.77 & 8.3 & 2.6 & 0.94 & 3.41 & 0.6 & 4.31 & 0.88 & 2.45 & 0.4 & 2.6 & 0.38 \\
\hline Eastern metabasalt & FD-37-009 & 5.7 & 11.7 & 1.61 & 7.9 & 2.4 & 0.86 & 3.31 & 0.59 & 4.05 & 0.83 & 2.54 & 0.38 & 2.4 & 0.37 \\
\hline Eastern metabasalt & FD-37-011 & 6.1 & 12.7 & 1.82 & 8.4 & 2.5 & 0.96 & 3.46 & 0.6 & 3.96 & 0.87 & 2.63 & 0.37 & 2.5 & 0.41 \\
\hline Eastern metabasalt & FD-37-012 & 6.3 & 14.1 & 2.02 & 10 & 3.3 & 1.16 & 4.49 & 0.77 & 5.42 & 1.11 & 3.33 & 0.49 & 3.3 & 0.48 \\
\hline Eastern metabasalt & FD-37-013 & 4.6 & 11.2 & 1.7 & 8.9 & 2.7 & 0.97 & 4 & 0.71 & 4.35 & 0.96 & 2.86 & 0.47 & 2.7 & 0.43 \\
\hline Eastern metabasalt & FD-37-015 & 6.9 & 12.9 & 1.91 & 9.2 & 3 & 1.07 & 4.21 & 0.73 & 4.82 & 1.06 & 3.12 & 0.46 & 3 & 0.5 \\
\hline
\end{tabular}




\begin{tabular}{|c|c|c|c|c|c|c|c|c|c|c|c|c|c|c|c|}
\hline Eastern metabasalt & FD-37-016 & 6.9 & 14.8 & 2.32 & 11.1 & 3.7 & 1.27 & 4.86 & 0.87 & 5.5 & 1.22 & 3.64 & 0.52 & 3.4 & 0.54 \\
\hline Eastern metabasalt & FD-37-019 & 7.1 & 14.1 & 1.95 & 9.3 & 2.8 & 1 & 3.62 & 0.67 & 4.45 & 0.96 & 2.81 & 0.42 & 2.8 & 0.46 \\
\hline Eastern metabasalt & FD-016 & 7.4 & 12 & 1.94 & 9 & 2.6 & 0.94 & 3.78 & 0.65 & 4.42 & 0.92 & 2.93 & 0.39 & 2.6 & 0.4 \\
\hline Eastern metabasalt & FD-028 & 5.7 & 13.1 & 1.99 & 10.2 & 3.2 & 1.12 & 4.34 & 0.72 & 4.82 & 1 & 2.92 & 0.44 & 2.9 & 0.42 \\
\hline Western metabasalt & RR-022 & 18.6 & 27.6 & 4.74 & 19.2 & 4.8 & 1.42 & 4.98 & 0.84 & 5.49 & 1.14 & 3.28 & 0.48 & 3.1 & 0.44 \\
\hline Western metabasalt & RR-F1-001 & 21.1 & 39.1 & 5.18 & 20 & 4.7 & 1.41 & 5.23 & 0.84 & 5.07 & 0.98 & 2.72 & 0.38 & 2.6 & 0.41 \\
\hline Western metabasalt & RR-F4-006 & 23 & 44.3 & 5.6 & 23.4 & 5.5 & 1.54 & 6.15 & 1 & 6.56 & 1.33 & 4 & 0.57 & 3.8 & 0.56 \\
\hline Western metabasalt & RR-F4-007 & 25 & 45.8 & 5.79 & 23.4 & 5.6 & 1.59 & 6.4 & 1.04 & 6.79 & 1.31 & 3.94 & 0.56 & 3.7 & 0.58 \\
\hline Western metabasalt & RR-F6-001 & 25.8 & 48.7 & 6.24 & 24.9 & 5.7 & 1.45 & 6.51 & 1.06 & 6.74 & 1.32 & 3.79 & 0.59 & 3.7 & 0.55 \\
\hline Western metabasalt & RR-F6-002 & 26.5 & 55.2 & 7.1 & 28.2 & 6.8 & 1.67 & 7.62 & 1.22 & 7.71 & 1.56 & 4.58 & 0.66 & 4.4 & 0.64 \\
\hline Western metabasalt & RR-F6-003 & 27.7 & 47.5 & 5.96 & 24.3 & 5.8 & 1.63 & 6.67 & 1.1 & 6.86 & 1.42 & 4.26 & 0.67 & 4 & 0.66 \\
\hline Western metabasalt & RR-F6-004 & 23.9 & 45.4 & 5.88 & 23.6 & 5.9 & 1.4 & 6.56 & 1.08 & 6.87 & 1.41 & 3.99 & 0.6 & 3.8 & 0.54 \\
\hline Western metabasalt & RR-F6-005 & 23.4 & 45.9 & 5.91 & 24.2 & 5.8 & 1.72 & 6.58 & 1.06 & 6.59 & 1.38 & 4.26 & 0.58 & 3.9 & 0.6 \\
\hline Western metabasalt & RR-F6-006 & 21.7 & 45.1 & 5.82 & 23 & 5.7 & 2.06 & 6.48 & 1 & 6.67 & 1.37 & 4.12 & 0.56 & 3.8 & 0.58 \\
\hline Western metabasalt & RR-F6-007 & 22.2 & 45.8 & 6.05 & 24.2 & 5.8 & 2.01 & 6.86 & 1.09 & 6.9 & 1.39 & 4.13 & 0.59 & 3.9 & 0.6 \\
\hline Western metabasalt & RR-F6-008 & 23.9 & 48 & 6.04 & 24.8 & 6 & 1.93 & 6.65 & 1.05 & 6.62 & 1.32 & 3.99 & 0.6 & 3.8 & 0.58 \\
\hline Western metabasalt & RR-F6-009 & 21.3 & 44.8 & 5.84 & 23.9 & 5.9 & 1.82 & 6.59 & 1.02 & 6.79 & 1.36 & 4.15 & 0.57 & 3.8 & 0.57 \\
\hline Western metabasalt & RR-F6-010 & 23 & 44.3 & 5.79 & 23.6 & 5.4 & 1.56 & 6.8 & 1.04 & 6.61 & 1.36 & 4 & 0.66 & 3.8 & 0.61 \\
\hline Western metabasalt & RR-F6-016 & 10.9 & 19.2 & 2.35 & 9.5 & 2 & 0.53 & 2.59 & 0.43 & 3.01 & 0.72 & 2.09 & 0.33 & 2.2 & 0.34 \\
\hline Western metabasalt & RR-F6-018 & 16.2 & 31.8 & 3.92 & 15.7 & 3.4 & 0.98 & 3.88 & 0.61 & 3.66 & 0.77 & 2.34 & 0.34 & 2.1 & 0.35 \\
\hline Western metabasalt & RR-F16-027 & 24.1 & 30.9 & 3.65 & 14.2 & 3.1 & 0.83 & 3.61 & 0.56 & 3.64 & 0.75 & 2.17 & 0.35 & 2.1 & 0.33 \\
\hline Metadacite & FD-052 & 16.3 & 29.8 & 2.97 & 12.4 & 2.8 & 0.69 & 2.62 & 0.43 & 2.81 & 0.52 & 1.54 & 0.18 & 1.3 & 0.16 \\
\hline Metarhyolite & RR-FST-002 & 35.5 & 64.4 & 6.27 & 23.9 & 4.4 & 0.94 & 4.09 & 0.6 & 3.66 & 0.73 & 2.25 & 0.27 & 2.2 & 0.26 \\
\hline
\end{tabular}

Table 5: Whole-rock trace and minor element chemical data (ppm).

\begin{tabular}{|c|c|c|c|c|c|c|c|c|c|c|c|c|c|c|c|}
\hline Unit and classification & Sample ID & Cs & Ba & Th & $\mathbf{U}$ & Ta & $\mathbf{N b}$ & $\mathbf{Z r}$ & Hf & Ti & $\mathbf{Y}$ & $\mathrm{Sr}$ & $\mathbf{R b}$ & $\mathbf{N i}$ & $\mathbf{V}$ \\
\hline \multicolumn{16}{|l|}{$\begin{array}{c}\text { Mundo Novo greenstone } \\
\text { belt }\end{array}$} \\
\hline Metakomatiite & RR-011B & 0.37 & 5 & 1.2 & 0.35 & 0.025 & 2.45 & 13 & 0.53 & 1500 & 4.47 & 12 & 1.2 & 945 & 2.5 \\
\hline Metakomatiite & FD-37-017 & 0.51 & 176 & 2.8 & 1.38 & 0.3 & 1.69 & 43 & 1.31 & 1380 & 8.83 & 49 & 10.3 & 644 & 42 \\
\hline Metakomatiite & FD-058A & 0.06 & 42 & 2.6 & 0.72 & 0.36 & 1.27 & 20 & 0.63 & 420 & 10.47 & 5 & 1.6 & 587 & 2.5 \\
\hline Metakomatiite & FD-070 & 0.11 & 50 & 0.8 & 0.39 & 0.025 & 0.58 & 15 & 0.2 & 420 & 12.02 & 5 & 1 & 493 & 2.5 \\
\hline Eastern metabasalt & RR-006 & 0.76 & 104 & 0.5 & 0.16 & 0.025 & 3.3 & 40 & 1.27 & 4980 & 18.07 & 90 & 8.1 & 115 & 207 \\
\hline Eastern metabasalt & RR-011C & 1.52 & 134 & 2.3 & 0.66 & 0.17 & 7.32 & 93 & 2.48 & 7140 & 21.67 & 100 & 8.1 & 110 & 232 \\
\hline Eastern metabasalt & RR-014B & 0.13 & 122 & 0.8 & 0.13 & 0.025 & 2.66 & 69 & 1.96 & 6000 & 28.43 & 108 & 6.1 & 112 & 283 \\
\hline Eastern metabasalt & RR-018A & 0.3 & 110 & 1.8 & 0.31 & 0.025 & 5.3 & 77 & 2.15 & 6240 & 26.24 & 109 & 4 & 112 & 295 \\
\hline Eastern metabasalt & RR-018B & 0.21 & 80 & 1 & 0.27 & 0.025 & 3.59 & 67 & 1.87 & 6420 & 24.46 & 120 & 5.8 & 110 & 306 \\
\hline Eastern metabasalt & RR-018C & 0.17 & 132 & 1.8 & 0.42 & 0.025 & 9.69 & 75 & 1.99 & 6600 & 27.2 & 128 & 2.1 & 112 & 306 \\
\hline Eastern metabasalt & RR-018D & 0.16 & 119 & 2.7 & 0.42 & 0.34 & 7.56 & 72 & 2.07 & 6360 & 25.88 & 162 & 1.8 & 109 & 292 \\
\hline Eastern metabasalt & RR-071 & 0.77 & 73 & 2.3 & 0.31 & 0.025 & 5.52 & 84 & 2.52 & 8760 & 22.27 & 66 & 5.2 & 92 & 306 \\
\hline Eastern metabasalt & RR-072 & 0.36 & 30 & 1.1 & 0.29 & 0.025 & 4.77 & 88 & 2.71 & 9120 & 22.77 & 185 & 4 & 97 & 315 \\
\hline Eastern metabasalt & RR-078 & 0.25 & 242 & 0.8 & 0.29 & 0.025 & 3.08 & 69 & 2.23 & 6900 & 28.29 & 94 & 7.6 & 125 & 315 \\
\hline Eastern metabasalt & RR-080 & 0.27 & 102 & 0.9 & 0.39 & 0.025 & 2.91 & 83 & 2 & 5820 & 24.88 & 133 & 11.7 & 124 & 386 \\
\hline Eastern metabasalt & FD-37-001 & 0.2 & 108 & 0.4 & 0.35 & 0.025 & 2.26 & 78 & 1.97 & 5820 & 22.32 & 109 & 2.6 & 90 & 366 \\
\hline Eastern metabasalt & FD-37-002 & 0.17 & 46 & 0.1 & 0.22 & 0.025 & 1.93 & 69 & 1.99 & 5880 & 22.86 & 110 & 2.8 & 108 & 371 \\
\hline Eastern metabasalt & FD-37-004 & 0.09 & 40 & 0.4 & 0.23 & 0.025 & 2.46 & 85 & 2.28 & 6660 & 27.81 & 107 & 2.3 & 72 & 423 \\
\hline Eastern metabasalt & FD-37-005 & 0.07 & 34 & 0.4 & 0.26 & 0.025 & 2.75 & 91 & 2.36 & 7260 & 29.87 & 127 & 1.6 & 62 & 425 \\
\hline
\end{tabular}




\begin{tabular}{|c|c|c|c|c|c|c|c|c|c|c|c|c|c|c|c|}
\hline Eastern metabasalt & D-37-006 & 0.41 & 53 & 0.05 & 0.18 & 0.025 & 1 & 48 & 1.37 & 4260 & 16.4 & 107 & 4.9 & 152 & 298 \\
\hline Eastern metabasalt & D-37-007 & 0.42 & 232 & 0.3 & 0.24 & 0.025 & 1.99 & 79 & 1.91 & 5940 & 23.31 & 122 & 6.6 & 142 & 362 \\
\hline Eastern metabasalt & FD-37-009 & 0.24 & 185 & 0.2 & 0.24 & 0.025 & 1.84 & 73 & 1.87 & 5580 & 22.88 & 117 & 3.3 & 164 & 374 \\
\hline Eastern metabasalt & FD-37-011 & 0.29 & 127 & 0.5 & 0.27 & 0.025 & 4.03 & 56 & 1.69 & 6120 & 22.3 & 111 & 4.7 & 148 & 299 \\
\hline Eastern metabasalt & FD-37-012 & 0.12 & 40 & 0.4 & 0.27 & 0.025 & 3.5 & 96 & 2.41 & 7380 & 28.27 & 109 & 2 & 49 & 490 \\
\hline Eastern metabasalt & FD-37-013 & 0.41 & 54 & 0.05 & 0.21 & 0.025 & 2.23 & 73 & 1.93 & 5940 & 22.35 & 113 & 4.6 & 106 & 379 \\
\hline Eastern metabasalt & FD-37-015 & 0.51 & 116 & 0.2 & 0.27 & 0.025 & 2.62 & 87 & 2.15 & 6720 & 26.05 & 120 & 5.5 & 116 & 415 \\
\hline Eastern metabasalt & FD-37-016 & 1.29 & 768 & 5 & 0.47 & 1.61 & 4.5 & 96 & 3.96 & 7680 & 28.83 & 107 & 32.9 & 110 & 451 \\
\hline Eastern metabasalt & FD-37-019 & 0.09 & 35 & 0.7 & 0.27 & 0.025 & 2.52 & 77 & 2.16 & 5940 & 23.28 & 112 & 1.5 & 77 & 409 \\
\hline Eastern metabasalt & FD-016 & 0.32 & 161 & 1.5 & 0.36 & 0.14 & 2.64 & 78 & 2.09 & 6120 & 24.9 & 111 & 8.2 & 104 & 323 \\
\hline Eastern metabasalt & FD-028 & 0.92 & 56 & 0.7 & 0.21 & 0.17 & 2.92 & 75 & 1.91 & 7620 & 25.05 & 132 & 8.9 & 111 & 322 \\
\hline Western metabasalt & RR-022 & 0.31 & 78 & 1.9 & 0.46 & 0.32 & 5.25 & 87 & 2.36 & 5700 & 28.44 & 574 & 13.7 & 83 & 192 \\
\hline Western 1 & RR-F1-001 & 1.2 & 141 & 4.2 & 0.95 & 0.025 & 6.22 & 138 & 3.44 & 5940 & 25.4 & 127 & 16.3 & 148 & 257 \\
\hline Western metabasalt & RR-F4-006 & 2 & 72 & 3.4 & 1.06 & 15 & 7.06 & 169 & 4.5 & 7560 & 32.18 & 187 & 4.5 & 88 & 331 \\
\hline Western metabasalt & RR-F4-007 & 0.63 & 480 & 3.3 & 1.08 & 0.08 & 7.8 & 171 & 4.31 & 8100 & 35.3 & 180 & 46.2 & 89 & 338 \\
\hline Western metabasalt & RR-F6-001 & 1.6 & 216 & 4.4 & 1.39 & 0.26 & 9.05 & 177 & 4.94 & 8040 & 32.77 & 131 & 43.7 & 106 & 358 \\
\hline Western $n$ & RR-F6-002 & 1.9 & 188 & 4.3 & 1.3 & 0.24 & 8.7 & 192 & 5.27 & 9360 & 40.14 & 108 & 29.5 & 91 & 312 \\
\hline Western & $\mathrm{R}$ & 111 & 244 & 3. & 1.16 & 0.025 & 8.05 & 183 & 4.73 & 8700 & 36.53 & 127 & 19.8 & 97 & 366 \\
\hline Western metabasalt & RR-F6-004 & 1.31 & 184 & 3.3 & 1.09 & 0.025 & 7.05 & 161 & 4.52 & 7800 & 33.53 & 80 & 20.9 & 93 & 310 \\
\hline Western metabasalt & RR-F6-005 & 2.57 & 278 & 3.3 & 1.09 & 0.025 & 7.1 & 171 & 4.45 & 7680 & 34.07 & 205 & 19.2 & 92 & 316 \\
\hline Western metabasalt & RR-F6-006 & 0.46 & 228 & 3. & 1.11 & 5 & 7.49 & 167 & 4.41 & 8040 & 36.03 & 214 & 16.5 & 91 & 322 \\
\hline Wester & RR-F & 017 & 98 & 3. & 1.11 & 0.025 & 7.34 & 172 & 4.32 & 8400 & 35.58 & 148 & 2 & 86 & 322 \\
\hline Western metabasalt & RR-F6-008 & 1.01 & 157 & 3.2 & 1.01 & 0.025 & 6.82 & 163 & 4.46 & 7740 & 34.29 & 152 & 16.5 & 88 & 326 \\
\hline Western metabasalt & RR-F6-009 & 0.19 & 55 & 3.2 & 1.03 & 0.025 & 7.48 & 162 & 4.4 & 7980 & 37.08 & 204 & 3.3 & 93 & 319 \\
\hline Western metz & RR-F6-010 & 0.55 & 184 & 3.1 & 1.08 & 0.025 & 7.51 & 170 & 4.36 & 8400 & 34.44 & 171 & 12.2 & 89 & 328 \\
\hline Wester & RR-F6-016 & 2 & 130 & 2.8 & 0.96 & 0.025 & 4.54 & 130 & 3.07 & 4260 & 17.1 & 54 & 27.2 & 51 & 241 \\
\hline Western metabasalt & RR-F6-018 & 0.33 & 59 & 2.7 & 0.93 & 0.025 & 4.04 & 118 & 2.86 & 3780 & 20.71 & 220 & 4.3 & 82 & 221 \\
\hline Western metabasalt & RR-F16-027 & 0.55 & 136 & 3.1 & 1.08 & 0.31 & 2.85 & 121 & 2.82 & 4380 & 20.78 & 112 & 21.5 & 80 & 313 \\
\hline Metadacite & FD-052 & 3.29 & 553 & 7 & 5.24 & 1.01 & 9.57 & 83 & 2.72 & 2040 & 14.94 & 109 & 92.3 & 99 & 76 \\
\hline Metarhyolite & RR-FST-002 & 5.83 & 631 & 17.1 & 5.37 & 0.26 & 8.37 & 152 & 4.88 & 2460 & 19.91 & 144 & 95.3 & 49 & 67 \\
\hline
\end{tabular}

\section{Mundo Novo Greenstone Belt}

The bivariate diagrams of $\mathrm{TiO}_{2}$ and $\mathrm{Al}_{2} \mathrm{O}_{3}$ (the least mobile major elements), FeOt and $\mathrm{MgO}$ (mobile major elements), $\mathrm{Ni}$ (conservative trace element), Y (immobile trace element), and La and Ce (light REE) against $\mathrm{Zr}$ were drawn for the metakomatiite from the lower sequence and the eastern and western metabasalts and metadacite from the middle sequence of the MNGB; the diagrams are shown in Figure 7, and show important correlations. Zr was used as a crystal fractionation index because of its immobility during alteration and metamorphism and its large range of concentration in igneous suites, resulting from varying degrees of partial melting and fractional crystallization [22]. The $\mathrm{Zr}$ concentrations are 13-43 ppm in the metakomatiite, 40-192 ppm in the eastern and western metabasalts and 83-152 ppm in the metadacite. $\mathrm{TiO}_{2}$ defines a positive pattern versus $\mathrm{Zr}$, and the eastern and western metabasalts form separate groups with the same slope. The $\mathrm{Al}_{2} \mathrm{O}_{3}$ diagram features a positive asymptotic pattern in which the metakomatiite samples plot near the origin, the metabasalt samples form a trend where the western metabasalt exhibits relatively high values of $\mathrm{Al}_{2} \mathrm{O}_{3}$, and the metadacite is approximately aligned in the trend. Four distinct and dispersed groups are formed in the FeOt plot, possibly because of the mobility of Fe during the alteration. The negative asymptotic patterns in the $\mathrm{MgO}$ and $\mathrm{Ni}$ diagrams form highly defined trends that can be explained by the fractional crystallization of olivine and pyroxene in the metakomatiite and eastern and western metabasalts. Y, La and Ce, which are considered immobile elements, show highly defined positive correlations versus Zr. Therefore, they were used to demonstrate that the metakomatiite, eastern and western metabasalts and metadacite from the MNGB may be related by fractional crystallization. 

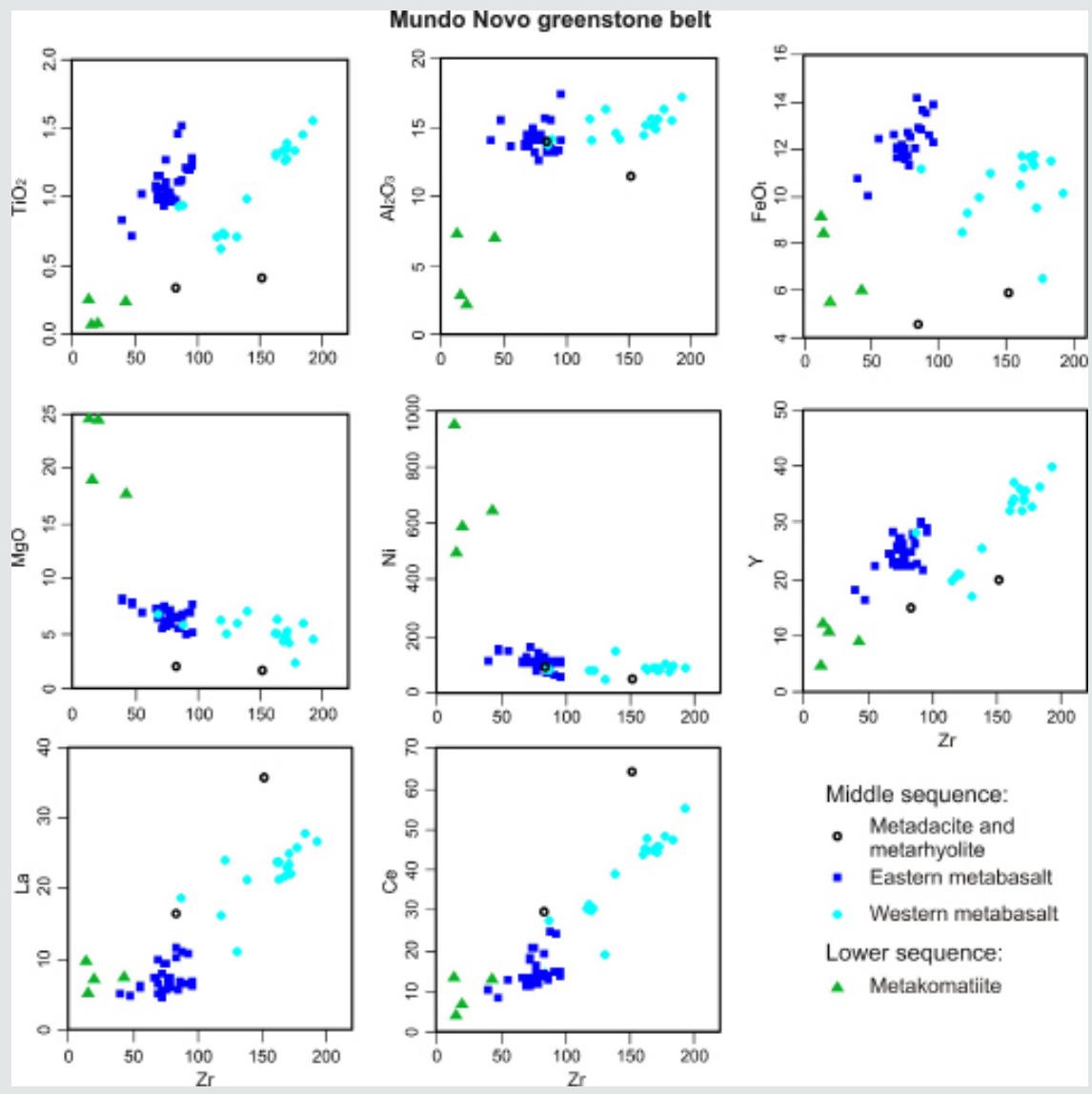

Figure 7: Binary plots using $\mathrm{Zr}$ as a differentiation index for the metavolcanic rocks of the MNGB..

\section{Lower Sequence}

The metakomatiite of the MNGB is peridotitic, with $\mathrm{MgO}$ concentrations of 17-25 wt.\% Figure 8a, and plots near the MgO vertex in the AFM diagram [73] Figure 8B. The chondrite normalized REE geochemical pattern [67] indicates enrichment in light REE in the metakomatiite in the MNGB, similar to the komatiite pattern from the Onverwacht Suite of the Barberton greenstone belt, South Africa [74] Figure 8d. The (La/Yb) N ratios in the MNGB's metakomatiite show low values, with an average of approximately 5 and a minimum of 2.69 . The low values of $\mathrm{Nb}(\leq 2.45 \mathrm{ppm})$, $\mathrm{Ti}$ $(\leq 0.150 \mathrm{ppm})$ and the Ti/Zr ratio $(\leq 0.012)$, in addition to the enrichment in $U$ and Th can be observed in Figure 9A. High $\mathrm{CaO} /$ Al203 ratios [75] in the metakomatiite of the MNGB, between 1.1 and 2.6, allow this rock to be classified as Al-depleted. In addition, the high (Gd/Yb) $N$ ratios [75] between 1.09 and 1.60 indicate partial melting at high pressures and that the garnet remained in the residue during the melting process. In the multielement diagram normalized to N-MORB [68], the Cs, Ba, Th and U elements show high and anomalous concentrations in the metakomatiite Figure 9A, a flat pattern from $\mathrm{Lu}$ to $\mathrm{Nd}$ and a negative anomaly of $\mathrm{Nb}$. The tectonic setting discrimination diagram of immobile elements, the $\mathrm{Nb} / \mathrm{Yb}$ vs. $\mathrm{Th} / \mathrm{Yb}$ diagram, indicates that the metakomatiite plots form a trend with other mafic volcanic rocks of the MNGB which extends from N-MORB point to volcanic arc array Figure 9E. This displacement of the plots oblique to MORB-ocean island basalt (OIB) array is a result of the transportation of subduction-mobile Th content $[16,76]$.

\section{Middle Sequence}

The division of MNGB metabasalt into the two eastern and western groups, as previously discussed based on petrography, was further confirmed by the REE pattern. REE patterns are reliable because of the immobility of these elements during lowgrade metamorphism, weathering and hydrothermal alteration, and therefore, a degree of confidence can be placed in the obtained patterns [77]. The two groups have subtle differences. The eastern metabasalt has higher percentages of $\mathrm{Fe}$ and $\mathrm{Ti}$ than the western metabasalt Figure 8A, which suggests a small andesitic trend in some western metabasalt samples. In the AFM diagram, two distinct groups of samples are also present, both in the tholeiitic series field, with just two samples of western metabasalt plotting in the calc-alkalic series field Figure 8B. In the chondrite normalized REE diagram [67], the western metabasalt is more fractionated and enriched in light REE, with La normalized values near 100, than the eastern metabasalt, which shows a flat REE pattern and La normalized values between 10 and 40 Figures 8E and 8F. The fractionation difference is also observed in the average (La/Yb) $\mathrm{N}$ ratio: the western metabasalt has a value of 5.11 and the eastern metabasalt has a value of 1.91 . 

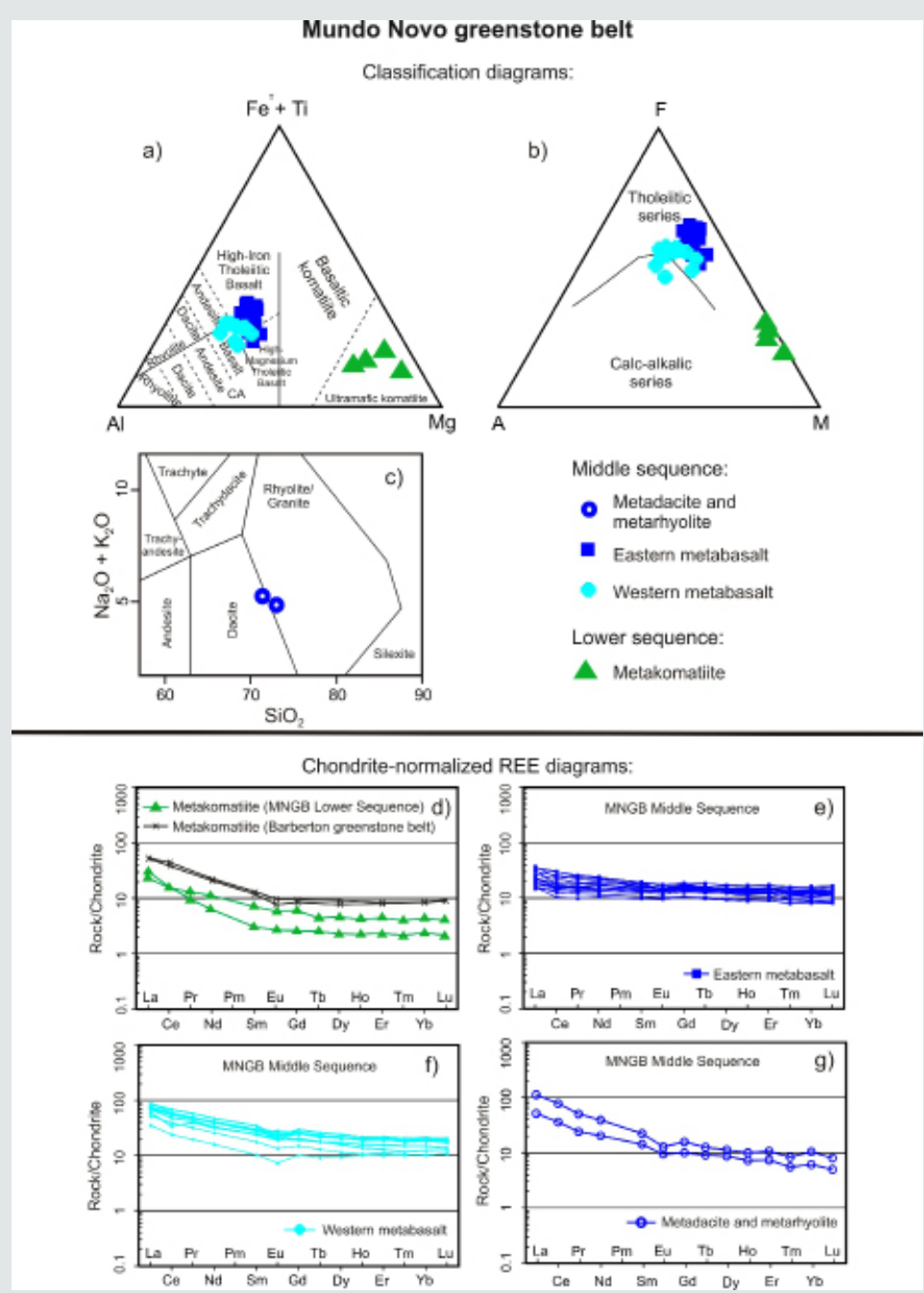

Figure 8: Lithochemical diagrams for MNGB rocks. A) Classification diagram [82]: $\mathrm{Fe}^{\mathrm{T}}+\mathrm{Ti}=\mathrm{FeO}+\mathrm{Fe}_{2} \mathrm{O}_{3}+\mathrm{TiO}_{2} ; \mathrm{Al}^{2} \mathrm{Al}_{2} \mathrm{O}_{3}$; $\mathrm{Mg}=\mathrm{MgO}$. B) AFM diagram, tholeiitic and calc-alkalic series [73], $\mathrm{A}=\mathrm{Na}_{2} \mathrm{O}+\mathrm{K}_{2} \mathrm{O} ; \mathrm{F}=\mathrm{FeO}+0.8998 \mathrm{Fe}_{2} \mathrm{O}_{3} ; \mathrm{M}=\mathrm{MgO} \mathrm{C}$ ) $\mathrm{SiO}_{2}$ vs. $\mathrm{Na}_{2} \mathrm{O}+\mathrm{K}_{2} \mathrm{O}$ classification diagram [79]. Chondrite-normalized REE diagram [67]: D) Metakomatiite in the MNGB lower sequence compared to the metakomatiite in the Barberton greenstone belt [74]; E) eastern metabasalt in the MNGB middle sequence; F) western metabasalt in the MNGB middle sequence; and G) metadacite and metarhyolite in the MNGB middle sequence.

The geochemical patterns of the major and trace elements normalized to the fertile mantle MORB (FMM) values as a tectonic setting marker [78] are similar for both metabasalt types of the MNGB. The patterns in which normalized $\mathrm{Nb}$ (24.06) and $\mathrm{Zr}$ (11.48) > TiO2 (6.47) and in which $\mathrm{Y}$ (6.98) and $\mathrm{Yb}(7.04) \geq \mathrm{CaO}$ (3.00), $\mathrm{Al}_{2} \mathrm{O}_{3}$ (3.91) and $\mathrm{V}$ (4.20) into the two metabasalts are similar to the patterns in ocean floor basalts in a back-arc basin setting, as demonstrated in the Barberton greenstone belt [22]. In the multielement diagram of trace elements normalized to N-MORB [68] Figures 9B and 9C, both metabasalt groups show a flat pattern from Lu to $\mathrm{Zr}$ and a negative Ta anomaly. The difference between the two groups is subtle but consistent. The negative $\mathrm{Ti}$ anomaly is more accentuated in the western metabasalt than in the eastern metabasalt. The western metabasalt is more enriched in La, Ce and Nd than the eastern metabasalt, and the Th and Cs values of the western metabasalt (Th values greater than 10 and some values of Cs greater than 100) are greater than the values of the same elements in the eastern metabasalt (Th values smaller than 10 and Cs values between 20 and 30). The Nb/Yb vs. Th/Yb discrimination diagram of immobile elements in the eastern and western metabasalts of the MNGB indicates a trend that extends from N-MORB in the MORB-OIB array to the volcanic arc array, with a principal axis of dispersion of the plots oblique to the MORBOIB array Figure 9e. This pattern is similar to oceanic subductionrelated basalts of the Mariana Arc and Isua, Barberton and South Abitibi Archean greenstone belts Figure 9e. The eastern metabasalt has an IAT-type pattern, with some samples overlapping the MORB field, and the western metabasalt mainly features a MORB pattern with a few occurrences plotting in the within-plate basalt field (WPB; Figure 9F).

The felsic metavolcanic rocks of the middle sequence of the MNGB are classified as metadacite and subordinate metarhyolite in the $\mathrm{SiO} 2$ vs. $\mathrm{Na} 2 \mathrm{O}+\mathrm{K} 20$ diagram [79] Figure 8C. The chondrite normalized REE diagram [67] for these felsic metavolcanic rocks subtly slopes from $\mathrm{Lu}$ to $\mathrm{Gd}$ with a negative $\mathrm{Eu}$ anomaly Figure $8 \mathrm{G}$, as indicated by the average $\mathrm{Eu} / \mathrm{Eu}^{*}$ ratio of 0.64 . There is enrichment in light REE with strong fractionation from Sm to La, 
and the average of the $(\mathrm{La} / \mathrm{Yb}) \mathrm{N}$ ratio is 8.87 . In the N-MORBnormalized multielement diagram [68] Figure 9D, the metadacite is enriched in $\mathrm{Nb}$ and $\mathrm{Ta}$; high $\mathrm{Cs}, \mathrm{Ba}$, Th and $\mathrm{U}$ values, a negative Ti anomaly and moderate values of Hf (2.72-4.88 ppm) and Zr (83$152 \mathrm{ppm}$ ) are shown. Moreover, the metadacite and subordinate metarhyolite plot in the volcanic arc field in the tectonic diagrams of Pearce et al. [80] Figures 9G and 9H and do not match the anorogenic field of the A-type granitoid diagram [81] Figure 9I according to the observations of metakomatiite and eastern and western metabasalts in the MNGB.
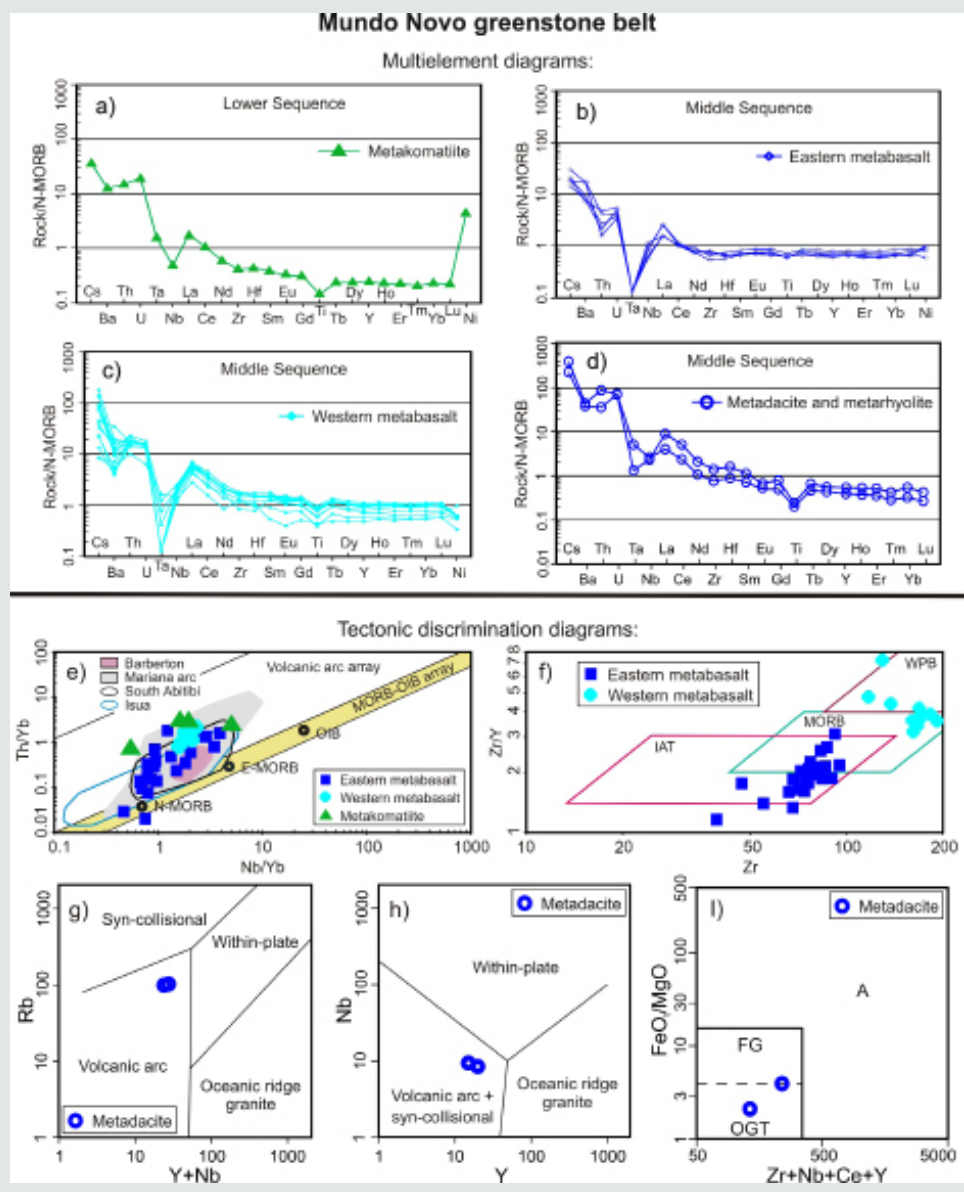

Figure 9: Lithochemical diagrams for MNGB rocks. A) Classification diagram [82]: $\mathrm{FeT}+\mathrm{Ti}=\mathrm{FeO}+\mathrm{Fe} 2 \mathrm{O} 3+\mathrm{TiO} 2 ; \mathrm{Al}=\mathrm{Al} 2 \mathrm{O} 3$; $\mathrm{Mg}=\mathrm{MgO}$. B) AFM diagram, tholeiitic and calc-alkalic series [73], $\mathrm{A}=\mathrm{Na} 2 \mathrm{O}+\mathrm{K} 2 \mathrm{O} ; \mathrm{F}=\mathrm{FeO}+0.8998 \mathrm{Fe} 2 \mathrm{O} 3 ; \mathrm{M}=\mathrm{MgO}$. C) $\mathrm{SiO} 2$ vs. Na2O + K2O classification diagram [79]. Chondrite-normalized REE diagram [67]: D) Metakomatiite in the MNGB lower sequence compared to the metakomatiite in the Barberton greenstone belt [74]; E) eastern metabasalt in the MNGB middle sequence; F) western metabasalt in the MNGB middle sequence; and G) metadacite and metarhyolite in the MNGB middle sequence.

\section{Discussion}

The fine-grained texture of the metakomatiite in the MNGB is composed of skeletal grains with planar growths that intersect each other and do not intercept former structures, which indicates a relict spinifex texture preserved in chilled margins of the komatiite flows. This spinifex texture in the metakomatiite and the occurrence of pillow lava structure in the eastern metabasalt suggest rapid and subaquatic crystallization such as that widely observed and interpreted in other greenstone belt terrains [13]. The recovery of the volcanic rocks of the MNGB composed of metachert and BIF by lithological association, the absence of zircon xenocrysts, the manganiferous ilmenite occurrence in the western metabasalt and the carbonate and argilic-chloritic hydrothermal alteration zones developed on the western metabasalt indicate ocean floor settings $[23,24,36,52,83]$.
Enrichments of $\mathrm{Cs}, \mathrm{Ba}$, Th and light REE relative to $\mathrm{Ta}, \mathrm{Nb}$, $\mathrm{Zr}, \mathrm{Hf}, \mathrm{Ti}, \mathrm{Y}$ and heavy REE and the flat pattern from $\mathrm{Lu}$ to $\mathrm{Nd}$ in the multielement diagram Figures 9A, 9B and 9C show that the metakomatiite and the two metabasalts of the MNGB were generated from the metasomatized mantle above the subducting altered oceanic crust; Furnes et al. [22] interpreted a similar enrichment in the Onverwacht Suite in the Barberton greenstone belt. However, the enrichment of light REE relative to heavy REE in the chondrite-normalized REE diagram [67] Figures 8E and $8 \mathrm{~F}$ was more accentuated in the tholeiitic-calc-alkalic western metabasalt relative to the tholeiitic eastern metabasalt, indicating stronger assimilation processes in the western metabasalt that must have been accentuated by the metamorphic events during the Rhyacian-Orosirian period.The effect of the heterogeneous crustal assimilation and metamorphism in the eastern and western metabasalts of the MNGB in the Paleoproterozoic may explain the 
differences in the mineral paragenesis. The eastern metabasalt, for example, is composed mainly of anorthite, bytownite, magnesiohornblende, ferrohornblende, augite, edenite and quartz; the western metabasalt comprises oligoclase, andesine, actinolite, ferrotschermakite, magnesiohornblende, biotite and quartz.

Both the eastern and western metabasalt samples of the MNGB plot in the IAT, MORB and WPB fields in the $\mathrm{Zr}$ vs. Zr/Y diagram Figure 9F; the eastern metabasalt plots in the IAT and MORB fields and the western metabasalt plots in the MORB and WPB field. The duplicity of fields by each metabasalt type appears initially uncertain; however, the proximity of settings during volcanism and the transition from one setting to other due to subsequent tectonic events with crustal assimilation must be considered. Therefore, the eastern and western metabasalts must be cogenetic and consistent with nearby intraoceanic settings in the MNGB, with different levels of crustal contamination during the formation in the oceanic crust by subduction components or intraoceanic contamination, and during metamorphism that probably occurred during the Rhyacian-Orosirian period. The stronger crustal assimilation in the western metabasalt displaces the plots to the WPB field, which is not observed in the eastern metabasalt plots. The plots of the metakomatiite and eastern and western metabasalts of the MNGB in the $\mathrm{Nb} / \mathrm{Yb}$ vs. $\mathrm{Th} / \mathrm{Yb}$ diagram feature a steep vector oblique to the MORB-OIB array Figure 9E. Those MNGB plots extend from near the N-MORB point, in the MORB-OIB array, and enter the field of the volcanic arc array, avoiding the OIB point. This plot distribution is similar to the South Abitibi [26,27], Barberton et al. [21,28,29] and Isua et al. [15,30] Archean greenstone belts Figure 9E, which are interpreted as an intraoceanic provenance as discussed in Pearce et al. [16], and similar to the modern Mariana intraoceanic arc-basin system [76]. Moreover, the MNGB geochemical pattern observed in the $\mathrm{Nb} / \mathrm{Yb}$ vs. $\mathrm{Th} / \mathrm{Yb}$ diagram shows that a subduction-related setting, in this case an intraoceanic arc, contributes to the increase in Th content in the rocks displacing the samples from the MORBOIB array to the volcanic arc array. However, the eastern metabasalt samples remaining in the MORB-OIB array register the initial ocean crust and back-arc setting in the MNGB and, with increasing island arc proximity, the plots displace from the MORB-OIB array. The samples most affected by tectonothermal Rhyacian-Orosirian events would be those most displaced from the MORB-OIB array and with higher Th content, such as the western metabasalt samples.

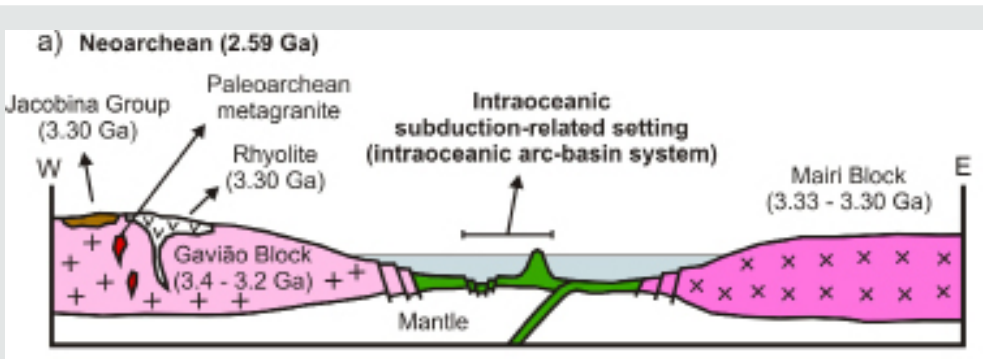

b) Rhyacian-Orosirian (2.1 - $1.97 \mathrm{Ga})$

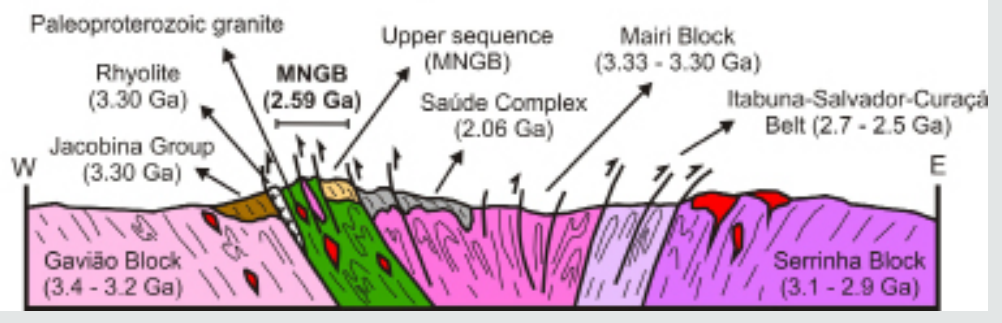

Figure 10: Intraoceanic setting proposed for the MNGB formation based on new data presented in this study and compiled ages for the Gavião Block, MNGB and Rhyacian-Orosirian granites [34,36,37,49,52,54], Mairi Block [50], Jacobina Group [35,54,55], Serrinha Block [34,44,45], Itabuna-Salvador-Curaçá Belt [41,42] and Saúde Complex [38,54]. A) Oceanic crust between the Gavião and Mairi blocks and formation of the MNGB at 2595 Ma. B) Rhyacian-Orosirian tectonic event that compressed the MNGB between the cratonic blocks of the eastern São Francisco Craton.

The metadacite samples of the MNGB in which feldspars were removed from the melt via crystal fractionation plot in the volcanic arc field in the diagrams of Pearce et al. [80] Figures 9G and 9H and do not match the anorogenic-type field in the diagram of Whalen et al. [81] Figure 9I, thus excluding intracratonic possibilities. In addition, the average $(\mathrm{La} / \mathrm{Yb}) \mathrm{N}$ ratio of 8.87 in the metadacite may be interpreted as an oceanic crust setting with a slight crustal contamination subducting the oceanic crust according to Condie and Kronër et al. [84]. Rios et al. [25] interpreted an intraoceanic setting with a back-arc provenance for basalts in the Neoarchean Contendas-Mirante volcano-sedimentary sequence, which is also inserted in the Contendas-Jacobina Lineament (southern part); this volcano-sedimentary sequence is similar and coeval relative to the MNGB. In the Archean Rio das Velhas greenstone belt, southern São Francisco Craton, ocean floor metabasalts and the felsic volcanic rocks were interpreted as occurrences of island arc or back-arc basin settings [23,24], which we also interpreted in the MNGB. An intracontinental provenance has been described for the Umburanas greenstone belt, in the southern part of the Gavião Block in the eastern São Francisco Craton [32], with deposition over a continental crust. This provenance suggests a diversity of settings for the greenstone belts in the eastern part of the São Francisco Craton, more specifically in the Gavião Block; alternatively, the crustal contamination and tectonism may have intensively altered 
the mineralogical and geochemical pattern of the rocks, making identification of the former oceanic crust difficult. Therefore, the intraoceanic arc-basin system appears suitable for defining the tectonic setting of the Neoarchean MNGB. The final amalgamation of the oceanic crust between the cratonic blocks Gavião, Mairi and Serrinha blocks and Itabuna-Salvador-Curaçá Belt of the northern and eastern São Francisco Craton in the Orosirian period [37] Figures $10 \mathrm{~A}$ and $10 \mathrm{~B}$ contributed to changing mineralogical and geochemical patterns that hid the primary oceanic crust signatures in the MNGB rocks.

\section{Conclusions}

a) The intraoceanic and intracontinental provenance of Archean greenstone belts are described in the Gavião Block, eastern São Francisco Craton. However, those greenstones or volcano-sedimentary sequences inserted into regional tectonic lineaments show lithological and geochemical patterns of intraoceanic provenances, such as the MNGB and the Contendas-Mirante volcano-sedimentary sequence; both of which are placed in the Contendas-Jacobina Lineament. The MNGB has geological and tectonic similarities relative to other greenstones in other regions of the São Francisco Craton, such as the Rio das Velhas greenstone belt in the metallogenic province of the Quadrilátero Ferrífero.

b) The volcanism in the MNGB was formed in an intraoceanic arc-basin system. The metakomatiite, eastern metabasalt and western metabasalt were formed in the near back-arc basin and island arc settings, mainly with MORB and IAT geochemical patterns. The tectonic processes in the oceanic arc systems enriched the $\mathrm{Cs}, \mathrm{Ba}$, Th and light REE content in the volcanic rocks. However, the compressional RhyacianOrosirian tectonothermal event contributed to accentuating the crustal assimilation, mainly in the western metabasalt that was directly affected by Gavião Block rocks during compressional tectonism, forming tectonic slices emplaced in the basement to the west of the MNGB. The metakomatiite and eastern metabasalt were mainly affected by intraoceanic assimilations and the Rhyacian-Orosirian tectonism may have been heterogeneous in these rocks, which preserved primary textures such as spinifex in the metakomatiite and primary structures such as pillow lava in the eastern metabasalt.

c) The mineralogical particularities between eastern and western metabasalts are products of the crustal assimilation during metamorphic processes in the Rhyacian-Orosirian. However, primary mineralogical differences can remain, since the volcanism is in nearby but different settings such as the back-arc basin and island arc.

d) The Neoarchean MNGB, formed in an intraoceanic arcbasin system, was compressed between cratonic blocks (Gavião, Mairi and Serrinha blocks and Itabuna-SalvadorCuraçá Belt) of the eastern São Francisco Craton during the Rhyacian-Orosirian period [37] Figures $10 \mathrm{~A}$ and 10B, thus forming the Contendas-Jacobina Lineament within which the greenstone was accommodated. After the RhyacianOrosirian compressional tectonothermal event, the MNGB was juxtaposed to the Paleoarchean Gavião Block to the west and south, the Paleoarchean Jacobina Group to the northwest and the Paleoarchean Mairi Block to the east, beyond the Rhyacian-Orosirian intrusion of granites. The formation of the siliciclastic metasedimentary rocks of the upper sequence of the MNGB and the Saúde Complex are interpreted as coeval to the Rhyacian-Orosirian event.

e) For improving the geological and petrological interpretations present in this manuscript, we recommend geochronological and $\mathrm{Nd}$ and $\mathrm{Sr}$ isotope studies of the metavolcanic rocks for a more thorough understanding of the tectonic setting during the formation of the MNGB.

\section{Acknowledgements}

This research was funded by the Companhia Baiana de Pesquisa Mineral and CAPES (Coordenação de Aperfeiçoamento de Pessoal de Nível Superior) and was linked to the PhD program of the Institute of Geosciences, Federal University of Bahia, Brazil.

\section{References}

1. Barbosa JSF, Sabaté P (2002) Geological features and the Paleoproterozoic collision of four Archean crustal segments of the São Francisco Craton, Bahia, Brazil. A synthesis. Rio de Janeiro, Anais da Academia Brasileira de Ciências 74(2): 343-359.

2. Barbosa JSF, Sabaté P (2003) Colagem paleoproterozoica de placas arqueanas do Cráton do São Francisco na Bahia. pp. 7-14.

3. Barbosa JSF, Sabaté P (2004) Archean and Paleoproterozoic crust of the São Francisco Craton, Bahia, Brazil: geodynamic features. Precambrian Research 133(1-2): 1-27.

4. Sabaté P, Marinho MM, Vidal P, Caen Vachette M (1990) The 2-Ga peraluminous magmatism of the Jacobina-Contendas Mirante belts (Bahia, Brazil): geologic and isotopic constraints on the sources. Chemical Geology 83(3-4): 325-338.

5. Mascarenhas JF, Guimarães JT, Moraes LC, Queiroz CJA, Marinho MM, et al. (1975) Projeto Bahia: Geologia da Folha de Senhor do Bonfim. Relatório Final. Salvador, Brazil.

6. Mascarenhas JF (1976) Estruturas do tipo greenstone belt no leste da Bahia. In: Congresso Brasileiro de Geologia. Belo Horizonte, Brazil 4: 2549.

7. Couto PA, Sampaio AR, Gil CAA, Loureiro HC, Arcanjo JB, et al. (1978) Projeto Serra de Jacobina: Geologia e Prospecção Geoquímica. Relatório Final. Salvador, Brazil.

8. Loureiro HSC (1991) Programa Levantamentos Geológicos Básicos do Brasil. Mundo Novo. Folha SC24-Y-D-IV. Estado da Bahia. Salvador, Brazil.

9. Mascarenhas JF, Silva EFA (1994) Greenstone Belt de Mundo Novo: caracterização e implicações metalogenéticas no Cráton do São Francisco.

10. Mascarenhas JF, Ledru P, Souza SL, Filho VMC, Melo LFA, et al. (1998) Geologia e recursos minerais do Grupo Jacobina e da parte sul do Greenstone Belt de Mundo Novo.

11. Zincone SA, Oliveira EP, Laurent O, Zhang H, Zhai M (2016) 3.30Ga High-Silica Intraplate Volcanic-Plutonic System of the Gavião Block, São Francisco Craton, Brazil: Implications of an intracontinental rift following the creation of insulating continental crust. Lithos 266: 414434 . 
12. Reis C, Menezes RCL, Miranda DA, Santos FP, Loureiro HC, et al. (2017) Mapa geológico-geofísico: Projeto ARIM Serra de Jacobina. Salvador, Brazil.

13. Anhaeusser CR (2014) Archaean greenstone belts and associated granitic rocks - A review. Journal of African Earth Sciences 100: 684-732.

14. Polat A, Kerrich R (2001) Magnesian andesites, Nb-enriched basaltandesites, and adakites from late-Archean 2.7 Ga Wawa greenstone belts, Superior Province, Canada: implications for late Archean subduction zone petrogenetic processes. Contributions to Mineralogy and Petrology 141(1): 36-52.

15. Polat A, Hoffmann AW, Rosing MT (2002). Boninite-like volcanic rocks in the 3.7-3.8 Ga Isua greenstone belt, West Greenland: geochemical evidence for intra-oceanic subduction zone processes in the early Earth. Chemical Geology 184(3-4): 231-254.

16. Pearce JA (2008) Geochemical fingerprinting of oceanic basalts with applications to ophiolite classification and the search for Archean oceanic crust. Lithos 100(1-4): 14-48.

17. Pearce JA (2014) Geochemical fingerprinting of the Earth's Oldest Rocks. Geology 42(2):175-176.

18. De Wit MJ, Hart RA, Hart RJ (1987) The Jamestown ophiolite complex, Barberton Mountain Belt: a section through 3.5 Ga oceanic crust. Journal of African Earth Sciences 6(5): 681-730.

19. Storey M, Saunders AD, Tarney J, Leat PT, Thirlwall MF, et al. (1988) Geochemical evidence for plume-mantle interactions beneath Kerguelen and Heard Islands, Indian Ocean. Nature 336:371-374.

20. Parman SW, Grove TL, Dann JC (2001) The production of Barberton komatiites in an Archean subduction zone. Geophysical Research Letters 28(13): 2513-2516.

21. Chavagnac V (2004) A geochemical and Nd isotopic study of Barberton komatiites (South Africa): implication for the Archean mantle. Lithos 75(3-4): 253-281.

22. Furnes H, de Wit M, Robins B (2013) A review of new interpretations of the tectonostratigraphy, geochemistry and evolution of the Onverwacht Suite, Barberton Greenstone Belt, South Africa. Gondwana Research 23(2): 403-428.

23. Zucchetti M, Lobato LM, Baltazar OF (2000) Volcanic and volcaniclastic features in Archean rocks and their tectonic environments, Rio das Velhas greenstone belt, Quadrilátero Ferrífero, MG - Brazil. Revista Brasileira de Geociências 30(3): 388-392.

24. Zucchetti M, Lobato LM, Baars FJ (2000a) Genetically diverse basalt geochemical signatures developed in the Rio das Velhas greenstone belt, Quadrilátero Ferrífero, Minas Gerais, Brazil. Revista Brasileira de Geociências 30(3): 397-402.

25. Rios CV (2017) Geologia isotópica das formações ferríferas bandadas do Cráton São Francisco na transição Arqueano Paleoproterozoico. PhD Thesis, Instituto de Geociências, Universidade de Brasília, Brasília, Brazil 243.

26. Kerrich R, Xie Q (2002) Compositional recycling structure of an Archean super-plume: Nb-Th-U-LREE systematics of Archean komatiites and basalts revisited. Contributions to Mineralogy and Petrology 142(4): 476-484.

27.Xie Q, Kerrich R (1994) Silicate-perovskite and majorite signature komatiites from the Archean Abitibi greenstone belt; implications for early mantle differentiation and stratification. Journal of Geophysical Research 99(B8): 15799-15812.

28. Jochum KP, Arndt NT, Hofmann AW (1991) Nb-Th-La in komatiites and basalts; constraints on komatiite petrogenesis and mantle evolution. Earth Planetary Science Letters 107(2): 272-289.

29. Parman SW, Dunn JC, Grove TL, De Wit MJ (1997) Emplacement conditions of komatiite magmas from the 3.49 Ga Komati Formation, Barberton greenstone Belt, South Africa. Earth and Planetary Science Letters 150(3-4): 303-323.
30. Polat A, Hoffmann AW (2003) Alteration and geochemical patterns in the 3.7-3.8 Ga Isua greenstone belt, West Greenland. Precambrian Research 126(3): 197-218.

31. Pearce JA (2005) Mantle preconditioning by melt extraction during flow: theory and petrogenetic implications. Journal of Petrology 46(5): $973-$ 997.

32. Leal LRB, Cunha JC, Cordani UG, Teixeira W, Nutman AP, et al. (2003) Shrimp U-Pb, 207Pb/206Pb zircon dating, and $\mathrm{Nd}$ isotopic signature of the Umburanas greenstone belt, northern São Francisco craton, Brazil. Journal of South American Earth Sciences 15(7): 775-785.

33. Bickle MJ, Nisbet EG, Martin A (1994) Archean greenstone belts are not oceanic crust. The Journal of Geology 102(2): 121-137.

34. Mougeot R (1996) Étude de la limite Archéen-Protérozoïque et des minéralisations $\mathrm{Au} \pm \mathrm{U}$ associées. Exemples de la région de Jacobina (Etat de Bahia, Brésil) et de Carajas (Etat de Para, Brésil). PhD Thesis, Université de Montpellier II, Montpellier, France 306.

35. Teles GS, Chemale F, Oliveira CG (2015) Paleoarchean record of the detrital pyrite-bearing, Jacobina Au-U deposits, Bahia, Brazil. Precambrian Research 256: 289-313.

36. Spreafico RR, Barbosa JSF, Barbosa NS, Moraes AMV, Souza Júnior FD (2018) A idade Neoarqueana (2,59 Ga, U-Pb) do greenstone belt Mundo Novo, Bahia, Brasil. In: 49 Congresso Brasileiro de Geologia. Rio de Janeiro, Brazil.

37. Leite CMM (2002) An Evolução Geodinâmica da Orogênese Paleoproterozóica nas Regiões de Capim Grosso, Jacobina e Pintadas - Mundo Novo (Bahia-Brasil): Metamorfismo, Anatexia Crustal e Tectônica. PhD Thesis, Universidade Federal da Bahia, Salvador, Brazil.

38. Zincone SA, Barbuena D, Oliveira EP, Baldim MR (2017) Detrital zircon $\mathrm{U}-\mathrm{Pb}$ ages as evidence for deposition of the Saúde Complex in a Paleoproterozoic foreland basin, northern São Francisco Craton, Brazil. Journal of South American Earth Sciences 79: 537-548.

39. Wilson N (1987) Combined Sm-Nd, $\mathrm{Pb}-\mathrm{Pb}$ and $\mathrm{Rb}-\mathrm{Sr}$ geochronology and isotope geochemistry in polymetamorphic precambrian terrains: examples from Bahia, Brazil and Channel Island. MS Dissertation, U.K. Master, Oxford University, England.

40. Silva LC, Armstrong R, Delgado IM, Pimentel M, Arcanjo JB, et al. (2002) Reavaliação da evolução geológica em terrenos Pré-Cambrianos brasileiros com base em novos dados U-Pb SHRIMP, Parte I: Limite centro-oriental do Cráton São Francisco na Bahia. Revista Brasileira de Geociências 32(4): 501-512.

41. Oliveira EP, Mcnaughton NJ, Armstrong R (2010) Mesoarchaean to Paleoproterozoic growth of the northern segment of the ItabunaSalvador-Curaçá orogeny, São Francisco Cráton, Brazil. In: Kusky, T.M., Zhai, M.G., Xiao, W. (Eds.), The evolving continents: understanding processes of continental growth. London, Geological Society Special Publication 338: 263-286.

42. Silva LC, McNaughton NJ, Melo RC, Fletcher IR (1997) U-Pb SHRIMP ages in the Itabuna-Caraíba TTG high-grade complex: the first window beyond the Paleoproterozoic overprinting of the eastern Jequié Craton, NE Brazil. In: Isgam International Symposium on Granites and Associated Mineralization. Salvador, Brazil, abstracts 1: 282-283.

43. Oliveira EP, Mello EF, Mcnaughton N (2002) Reconnaissance U-Pb geochronology of Precambrian quartzites from the Caldeirão belt and their basement, NE São Francisco Craton, Bahia, Brazil: implications for the early evolution of the Paleoproterozoic Itabuna-Salvador-Curaçá orogeny. Journal of South American Earth Sciences 15(3): 349-362.

44. Oliveira EP, Mello EF, McNaughton NJ, Choudhuri A (2002b) SHRIMP $\mathrm{U}-\mathrm{Pb}$ age of the basement to the Rio Itapicuru Greenstone Belt, NE São Francisco craton. In: $41^{\circ}$ Congresso Brasileiro de Geologia. João Pessoa, Brazil Anais pp. 522.

45. Rios DC, Davis DW, Conceição H, Davis WJ, Rosa MLS, et al. (2009) Geologic evolution of the Serrinha nucleus granite-greenstone terrane (NE Bahia, Brazil) constrained by U-Pb single zircon geochronology. Precambrian Research 170(3-4): 175-201. 
46. Barbosa JSF, Cruz SCP, Souza JS (2012a) Terrenos metamórficos do embasamento. In: Barbosa, J.S.F. (Ed.). Geologia da Bahia: Pesquisa e Atualização. Salvador, Brazil, CBPM pp. 101-201.

47. Barbosa JSF (1997) Síntese do Conhecimento sobre a Evolução Geotectônica das Rochas Metamórficas Arqueanas e Paleoproterozóicas do Embasamento do Cráton do São Francisco na Bahia. Revista Brasileira de Geociências 27(3): 241-256.

48. Leal LRB (1998) Geocronologia U/Pb (SHRIMP), 207Pb/206Pb, Rb/Sr, Sm/Nd e K/Ar dos Terrenos Granito-Greenstone do Bloco do Gavião: Implicações para a Evolução Arqueana e Paleoproterozoica do Cráton do São Francisco, Brasil. PhD Thesis, Universidade de São Paulo, São Paulo, Brazil pp. 178.

49. Peucat JJ, Mascarenhas JF, Barbosa JSF, Souza SL, Marinho MM, et al. (2002) 3.3 Ga SHRIMP U-Pb zircon age of a felsic metavolcanic rock from the Mundo Novo Greenstone Belt in the São Francisco Craton, Bahia (NE Brazil). Journal of South American Earth Sciences 15(3): 363-373.

50. Sousa DFM, Oliveira EP, Amaral WS (2018) Geologia e geocronologia $\mathrm{U}-\mathrm{Pb}$ em zircão de ortognaisses e K-granitoides relacionados ao Bloco Gavião (Complexo Mairi) e Cinturão Salvador-Curaçá - Região da Mina Caraíba - Bahia. In: $49^{\circ}$ Congresso Brasileiro de Geologia. Rio de Janeiro, Brazil, Anais, pp. 980.

51. Reis C, Oliveira RCL, Miranda DA, Santos FP, Guimarães JT, et al. (2018) Estratigrafia do grupo Jacobina. In: $49^{\circ}$ Congresso Brasileiro de Geologia. Rio de Janeiro, Brazil, Anais, pp. 1232.

52. Spreafico RR (2017) Projeto Mundo Novo: texto e mapas. Salvador, Brazil, CBPM, pp. 84.

53. 7 D, Oliveira EP, Zincone SA (2016) Estudos de proveniência dos quartzitos do Greenstone Belt Mundo Novo (BA) e implicações tectonoestratigráficas. In: $48^{\circ}$ Congresso Brasileiro de Geologia. Porto Alegre, Brazil, Anais, pp. 818.

55. Teles GS (2013) Proveniência e idades de deposição dos sedimentos auríferos da Bacia de Jacobina: Implicações sobre a evolução da bacia durante o Paleo-Arqueano e a gênese da mineralização. MS Dissertation, Instituto de Geociências, Universidade de Brasília, Brasília, Brazil, pp. 122.

56. Magee CW, Palin JM, Taylor WR (2001) Laser ICP-MS U/Pb analyses of detrital zircons from Proterozoic sediments in Bahia state, Brazil; implications for the evolution of the São Francisco craton prior to $3.3 \mathrm{Ga}$. In: 11th V.M. Goldschmidt Conference, Hot Springs, abstract 3501.

57. Leite CMM, Barbosa JSF, Nicollet C, Sabaté P (2007) Evolução metamórfica/metassomática paleoproterozóica do Complexo Saúde, da Bacia Jacobina e de leucogranitos peraluminosos na parte norte do Cráton do São Francisco. Revista Brasileira de Geociências 37(4): 777797.

58. Barbosa JSF, Pinto MS, Cruz SCP, Souza JS (2012b) Granitoides. In: Barbosa, J.S.F. (Ed.). Geologia da Bahia: Pesquisa e Atualização. Salvador, Brazil, pp. 327-396.

59. Kretz R (1983) Symbols for rock-forming minerals. American Mineralogist 68(1-2): 277-279.

60. Siivola J, Schmid R (2007) A systematic nomenclature for metamorphic rocks. 12. List of mineral abbreviations. Recommendations by the IUGS Subcommission on the Systematics of Metamorphic Rocks. Web version 01.02.07. IUGS Commission on the Systematics in Petrology.

61. Whitney DL, Evans BW (2010) Abbreviations for names of rock-forming minerals. American Mineralogist 95(1): 185-187.

62. Leake BE, Woolley AR, Arps CES, Birch WD, Gilbert MC, et al. (1997) Nomenclature of Amphiboles: Report of the Subcommittee on Amphiboles of the International Mineralogical Association Commission on New Minerals and Mineral Names. The Canadian Mineralogist 35(1): 219-246.

63. Morimoto N (1988) Nomenclature of pyroxenes. Mineralogy and Petrology 39(1): 55-76.
64. Lynch L (1996) Provisional elemental values for four new geochemical soil and till reference materials, TILL-1, TILL-2, TILL-3 and TILL-4. Geostandards and Geoanalytical Research 20(2): 277-287.

65. Thompson M (1988) Variation of precision with concentration in an analytical system. Analyst 113(10): 1579-1587.

66. Janousek V, Farrow CM, Erban V (2006) Interpretation of whole-rock geochemical data in igneous geochemistry: introducing Geochemical Data Toolkit (GCDkit). Journal of Petrology 47(6): 1255-1259.

67. Boynton WV (1984) Geochemistry of the rare earth elements: meteorite studies. In: Henderson, P. (Ed.). Rare Earth Element Geochemistry. Amsterdan, Netherlands Elsevier, pp. 63-114.

68. Hofmann AW (1988) Chemical differentiation of the Earth: the relationship between mantle, continental crust, and oceanic crust. Earth and Planetary Science Letters 90(3): 297-314.

69. Souza SL, Garrido IAA, Oliveira NS, Fróes RJ (2002) Projeto Greenstone Belt de Mundo Novo: estudos geológicos regionais. Salvador, Brazil, 1: 62.

70. Arndt NT (1994) Archean Komatiites. Developments in Pre CambrianGeology 1: 11-44.

71. Schmid R, Fettes D, Harte B, Davis E, Desmons J (2007) How to name a metamorphic rock. Recommendations by the IUGS Subcommission on the Systematics of Metamorphic Rocks. Web version 01.02.07. IUGS Commission on the Systematics in Petrology.

72. Fettes DJ, Desmons J, Árkai P, Brodie K, Bryhni I (2007) Metamorphic rocks: a classification and glossary terms. Cambridge pp. 244.

73. Irvine TN, Baragar WRA (1971) A guide to the Chemical Classification of the Common Volcanic Rocks. Canadian Journal of Earth Sciences 8(5): 523-548.

74. Jahn BM, Gruau G, Glikson AY (1982) Komatiites of the Onverwacht Group, S. Africa: REE Geochemistry, Sm/Nd Age and Mantle Evolution. Contributions to Mineralogy and Petrology 80(1): 25-40.

75. Herzberg C (1995) Generation of plume magmas through time: an experimental perspective. Chemical Geology 126(1): 1-16.

76. Pearce JA, Stern RJ, Bloomer SH, Fryer P (2005) Geochemical mapping of the Mariana Arc-Basin System: implications for the nature and distribution of subduction components. Geochemistry, Geophysics, Geosystems 6(7): 1-27.

77. Rollinson HR (1993) Using Geochemical Data: Evaluation, Presentation, Interpretation. England, Longman Scientific and Technical pp. 352.

78. Pearce JA, Parkinson I.J. (1993) Trace element models for mantle melting: application to volcanic arc petrogenesis. Magmatic Processes and Plate Tectonics. London, Geological Society of London Special Publication 76: 373-403.

79. Middlemost EAK (1994) Naming materials in the magma/igneous rock system. Earth Science Reviews 37(3-4): 215-224.

80. Pearce JA, Harris NBW, Tindle AG (1984) Trace element discrimination diagrams for the tectonic interpretation of granitic rocks. Journal of Petrology 25(4): 956-983.

81. Whalen JB, Currie KL, Chappell BW (1987) A-type granites: geochemical characteristics, discrimination and petrogenesis. Contributions to Mineralogy and Petrology 95(4): 407-419.

82. Jensen LS (1976) A new cation plot for classifying subalkalic volcanic rocks. Ontario, Ontario Division of Mines, Miscellaneous Paper 66: 22

83. Grachev AF, Pechersky DM, Tsel'movich VA (2011) Titanomagnetites and ilmenites from the Early Cenozoic Basalts and Limburgites of the Northern Tien Shan. Physics of the Solid Earth 47(6): 475-487.

84. Condie KC, Kronër A (2013) The building blocks of continental crust: Evidence for a major change in the tectonic setting of continental growth at the end of the Archean. Gondwana Research 23(2): 394-402. 
(C) (P) This work is licensed under Creative

To Submit Your Article Click Here: Submit Article

DOI: 10.32474/JOMME.2019.01.000105

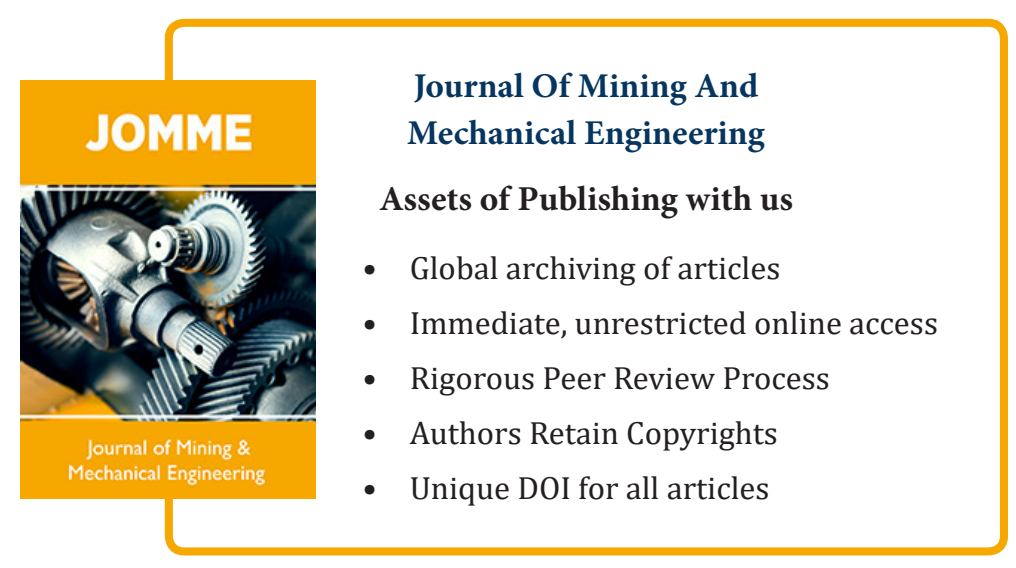

